\title{
Social Times of Network Spaces: Network Sequences and Foreign Investment in Hungary ${ }^{1}$
}

David Stark

Columbia University

Balázs Vedres
Central European University

To model, from its inception, interenterprise network formation and its interaction with foreign investment across an entire epoch of rapid and profound economic transformation, the authors gathered data on the complete ownership histories of 1,696 of the largest Hungarian enterprises from 1987 to 2001. They develop a social sequence analysis to identify distinctive pathways whereby firms use network resources to buffer uncertainty, hide or restructure assets, or gain knowledge and legitimacy. During this period, networked property grew, stabilized, and involved a growing proportion of foreign capital. Cohesive networks of recombinant property were robust, and in fact integrated foreign investment. Although multinationals, through their subsidiaries, dissolved ties in joint venture arrangements, the authors find evidence that they also built durable networks. These findings suggest that developing economies do not necessarily face a forced choice between networks of global reach and those of local embeddedness.

\begin{abstract}
Social structures often are made to seem the antipodes to, or at least unrelated to details and nuances of, sequencing in timing. This is in part because of the influence of structuralism. Social times should instead be accounted as much part of structure as are network spaces.-Harrison White (1992)
\end{abstract}

Business organizations today must cope with the challenges of a transforming global economy. Markets are volatile, technological change is rapid, and capital is mobile on an increasingly global scale. In settings of

\footnotetext{
${ }^{1}$ Research for this article was supported by a grant from the National Science Foundation (SES-01-36995). We also acknowledge the support of the Russell Sage Foun-

(C) 2006 by The University of Chicago. All rights reserved. 0002-9602/2006/11105-0003\$10.00
}

AJS Volume 111 Number 5 (March 2006): 1367-1411 
radical uncertainty, economic sociologists point to how firms cooperate in networks of strategic alliance (Kogut and Walker 2001; Powell et al. 2005; Stuart 1998; Uzzi 1997). New research in the sociology of development similarly addresses network conceptions of organization. Whether attentive to networks of "developmental associations" (Evans 1995), to "global commodity chains" (Gereffi and Fonda 1992), or to new conceptions of multinational corporations as transnational networks (Ghoshal and Bartlett 1990; Hedlund 1993), new research shifts focus from decision-making structures of boundedly rational actors to the structure of ties in which organizations are embedded (Morgan, Kristensen, and Whitley 2001). Sustainable growth is more likely, research suggests, where the subsidiaries of foreign companies are embedded in network ties within the host economy, as locals and foreigners alike recognize that business networks can be viewed as a strategic resource (Bair and Gereffi 2003; Dicken, Forsgren, and Malmberg 1994). From the earlier question of how a national economy is integrated into the global economy, a new agenda for the field of economic development asks whether and how foreign investment is integrated into the local networks of host economies.

This article furthers that agenda by analyzing the evolution of a national network of interorganizational ownership ties in its relationship to foreign direct investment (FDI). Can high levels of foreign investment be compatible with interenterprise ownership networks in a developing economy? Our analysis is conducted in a setting strategically chosen for extraordinarily high levels of foreign investment in a situation where domestic firms were forming diverse interorganizational ownership networks in response to high levels of uncertainty in their business environmentconditions marking the postsocialist Hungarian economy between 1987 and 2001. Our case represents one of the most rapid and far-reaching transformations of a national economy. During this period, the institutions of the Hungarian economy were fundamentally reorganized from planning to market coordination. The system of property was similarly transformed: our data reveal that state ownership of the large firm sector declined from $98 \%$ in 1987 to $15 \%$ in 2001, and the share of the large firm sector that was foreign owned rose from only $1 \%$ in 1987 to $53 \%$ in 2001.

dation and the Collegium Budapest. We benefited from discussions at the Santa $\mathrm{Fe}$ Institute, INSEAD, the Center on Organizational Innovation at Columbia University, and the Center for the Study of Economy and Society at Cornell University. For assistance, criticisms, and suggestions, we are grateful to Zsolt Batár, László Bruszt, Andrew Buck, Gil Eyal, Amanda Damarin, Neil Fligstein, Geoff Fougere, István Gábor, Paul Ingram, William McAllister, Andrew Spicer, Duncan Watts, Doug White, Harrison White, and especially Peter Bearman and Monique Girard. Direct correspondence to David Stark, Department of Sociology, Columbia University, 1180 Amsterdam Avenue, New York, New York 10027. E-mail: dcs36@columbia.edu 
To analyze how FDI interacts with evolving network structures, we gathered data on the complete ownership network histories of 1,696 of the largest Hungarian enterprises from 1987 to 2001. This time frame yields comprehensive coverage of the Hungarian economic transformation, reaching back to the moment when firms could register as corporations and encompassing the institutionalization of private property, market coordination, and foreign investment. Our time frame thus includes the entire period in which firms were privatized and new regulatory frameworks were established governing banking, bankruptcy, accounting, contracting, and corporate governance. We are therefore able to study, from its inception, network formation across an entire epoch of economic transformation.

We record network formation starting from the very first ownership ties made in a nascent market economy, where the legal possibility of creating an interfirm ownership tie coincides with the starting point of our data collection. We then follow network evolution over the turbulent years of postsocialism into market stabilization and the massive inflow of foreign investment. We will be especially attentive to differences between vertically organized business networks and those with more horizontal patterns of cohesion. We identify the emergence of varieties of both vertical and cohesive structures, and we follow these structures across time to understand their durability and openness to foreign investment. By utilizing the histories of firm network embeddedness, we are able to model how foreign investment interacts with these network forms.

To do so, we develop analytic tools that reconcile the structural focus of social network analysis with the historical orientation of sequence analysis. In combining the two approaches, we begin with the element that each shares-the notion that meaning is given by context (Abbott 1997). For the network analyst, no tie has meaning in itself. To interpret a tie, the analyst must understand its location in social space. In network analysis, context is topographic. For sequence analysts, as for historical sociologists more generally, no event has meaning in itself. The meaning of an action, an event, a social formation, or a relationship must be understood in its temporal context. In the theoretical approach that we are developing, structure is identified at the intersection of topographic and temporal contexts. As a parallel to social network analysis, we develop a social sequence analysis. To do so we study variation in the sequences of local network positions. Our combination of network analysis and sequence analysis is, thus, not merely additive: in striving to make network analysis historical we also seek to make sequence analysis relational. At the basis of our project of historical network analysis is a reconstruction of the network sequences of 1,696 firms. Identifying distinctive pathways 
through a network space, we argue, is a way to understand processes of network evolution.

Our analysis indicates, first, that high levels of FDI are compatible with the persistence of domestic interenterprise ownership networks. Globalization and the reproduction of network embeddedness are not necessarily mutually opposing processes. Second, we find that the Hungarian economy is not a dual-segregated economy composed of domestic firms that are networked and foreign-controlled firms that are isolated. In fact, the proportion of Hungary's mixed economy that is controlled by foreign owners and linked to domestic ownership networks has been increasing from 1991 to 2001. By 2001, only 30\% of foreign capital is invested in subsidiaries that have never been part of ownership networks. Foreignowned firms were just as likely to have ties to domestically owned firms as to other foreign-owned firms: we find no evidence for segregation. We find, third, that network forms of "recombinant property" (Stark 1996) are robust throughout the period. Notably, one variant of recombinant property, characterized by cohesive network structures, is most likely to involve the participation of foreign investment. More than a mere legacy of state socialism, these network forms are a viable organizational response to the challenges of an internationalized economy. Fourth, using logistic regression analysis we find that the odds of involving sizable foreign ownership differ significantly across distinctive pathways of network positions. Fifth, we find that the subsidiaries of foreign multinationals are not simply joining existing network structures but are actively participating in network creation and growth. In Hungary, foreign investment and network evolution are intertwined processes.

The next section presents the basic contours of our case- - the Hungarian economy after the collapse of state socialism, the subsequent emergence of interenterprise networks, the demise of state ownership, and the rise of foreign investment. Following this discussion, we then frame our theoretical and methodological contribution as an attempt to model the structure of network practices through combined attention to topography and temporality. After describing our data collection, we chart the changing proportions of the Hungarian economy that are foreign or domestic and networked or isolated.

To identify the microprocesses of interorganizational network formation that explain the macrostructural outcomes, we move to modeling that makes sequences of network positions the unit of analysis. The methodological innovation at the core of this study is to combine the tools of sequence analysis and network analysis to yield a sequence analysis of changing network positions. We first define discrete forms of embeddedness. These local network topographies are the building blocks to identify sequences of changes in forms of embeddedness for each of the firms in 
our population. Next, we describe the optimal matching operations for grouping firms on the basis of similarities in sequence patterns through that network space. Using logistic regression analysis we test our proposition that foreign ownership can be explained not simply by the shape of network structures but by the sequencing of network positions. We then discuss in detail the typical pathways and their coevolution with foreign investment. Recognizing that relational resources can be used for different organizing purposes, we interpret the temporal patterns of network properties to understand the interdependent practices of Hungarian managers and foreign investors.

\section{THE DOMESTIC EMBEDDEDNESS OF FOREIGN INVESTMENT}

\section{Emergence of Interenterprise Ownership Networks}

The postsocialist economies of Eastern Europe and the former Soviet Union offer a striking laboratory to study processes of network formation in a period of rapid and far-reaching economic change. In their extrication from state socialism, postsocialist firms confronted highly uncertain political, economic, and institutional environments. With the demise of the old COMECON (Council for Mutual Economic Assistance) alliance that regulated trade among the socialist economies, firms watched the collapse of their once-secure trading partners. Literally within a month, and not at the margin but in overwhelming proportions, they had to seek new suppliers and new customers. They would do so in an institutional environment of extreme complexity. Newly elected democratic governments were dismantling the socialist planning apparatus and launching ambitious programs of privatization. From one month to the next, government agencies promulgated regulations governing banking, bankruptcy, accounting, contracting, FDI, and corporate governance. For firms remaining in state ownership, for recently "privatized" firms, and for new startup firms alike, the challenge was to navigate through a maze of new policies in which contradictory regulations and inconsistent enforcement produced ambiguity about which rules and which games were operating.

Earlier work (Stark 1996) drew on insights that interorganizational ties might provide means to cope with highly uncertain environments. Based on data gathered through complementary research methods (ethnographic research in firms, the analysis of government agency documents, and the analysis of the ownership records of the 200 largest Hungarian enterprises and top 25 banks in 1994), this work identified an ensemble of practices labeled recombinant property. Interenterprise ownership networks were a response to uncertainty (Stark 1996) and served as a strategy to spread risk (see also Johnson 1997; McDermott 1997; Róna-Tas 1998; Spicer, 
McDermott, and Kogut 2000; Böröcz 2001; Vedres 2000). Like mountain climbers assaulting a treacherous face, postsocialist firms used networks of cross-ownership as the safety ropes binding them together.

Along with identifying and labeling this new process came the warning that recombinant property might increase chances of survival without increasing profitability. Some firms were diversifying their portfolio of resources (blurring the boundaries of public and private) for the purpose of socializing liabilities while privatizing assets (Stark 1996, pp. 1012-15). Similarly, business group networks were a means not only of risk spreading but of risk shedding in a context in which policies of credit worthiness and debt forgiveness were highly politicized (Stark 1996, pp. 1009-12). Thus, networked assets could facilitate productive restructuring; but they also offered avenues to exploit ambiguities in regulations and offload liabilities to the taxpayer in state-sponsored programs of bank bailouts and debt forgiveness (Stark 1996). ${ }^{2}$

The research on recombinant property was conducted while levels of foreign investment were modest, during the period of uncertainty when new regulatory frameworks had been introduced but were not yet institutionalized. Since then, extrication from state socialism has been decisive: the planned economy and the dominance of state ownership have been systematically dismantled. Similarly, the entrance of foreign investment has been massive: the Hungarian economy today is arguably one of the most globalized economies in the world. What, then, has happened to interorganizational ownership networks over the entire period of transformation from 1987 to 2001?

\section{Foreign Investment Meets Postsocialist Networks}

The existing literature on foreign investment and network forms in postsocialist settings suggests at least three possibilities. One possibility is that the shock of system change will produce early patterns of network formation that reach a tipping point to a self-reinforcing dynamic of almost unchecked network growth. Business groups would be strong, partly because they are densely connected and also because they link deeply into the political class. These domestic networks might then lock out foreign capital, perhaps even dispelling some initial foreign investors. ${ }^{3}$ In terms of the relative proportions of the economy that are networked or isolated,

\footnotetext{
2 "Centralized management of liabilities will not continue indefinitely, but the organizational dynamics of enterprises formed under the new paternalistic conditions are likely to have strong path-dependent effects" (Stark 1996, p. 1012).

${ }^{3}$ For the Hungarian case, where we know that foreign investment continued to grow, this first scenario is obviously counterfactual but, nonetheless, heuristically useful.
} 
foreign or domestic, this would be a case where, at the extreme, almost everything is networked and domestically controlled. Even the modest levels of foreign investment would be bound to domestic business groups. This process of network crowding would correspond to the antidevelopmental lines of the contemporary Russian economy analyzed by Burawoy (Burawoy 1996; Burawoy and Krotov 1992) and others (Johnson 1997; Zon 1998).

A second possibility is that extraordinarily high levels of foreign investment will lead to the eradication of interenterprise ownership. This expectation corresponds closely to the view of Hanley, King, and Tóth (2002) who, in challenging the recombinant-property approach, argue that interenterprise ownership networks were a transient and fleeting phenomenon, confined to the period immediately following the collapse of state socialism. The eradication of these interenterprise ownership ties, according to Hanley and his coauthors, has been carried out by "private parties" exercising "clear and unambiguous ownership rights" (Hanley et al. 2002, p. 140) - in particular by foreign investors who, in their view, desire strong and unambiguous lines of control, undiluted by ownership network ties. Interenterprise ownership links that preceded foreign investment would be broken up when foreigners acquired firms through the privatization process. Moreover, given the powerful influence of foreign firms (rich in resources-financial, managerial, and ideological), their predilection to shun network ties would rapidly diffuse throughout the economy. The result of the direct actions of the foreign multinationals as well as of these indirect demonstration effects would be, at the extreme, an economy opposite to the first possibility—almost nothing would be networked.

A third expectation describes a segregated, dual economy as increasing levels of foreign investment leads to a radical separation between foreign and domestic firms. Foreign investment, in this view, results in "cathedrals in the desert" (Grabher 1994; Hardy 1998; Pavlinek and Smith 1998; Uhlir 1998). These are platform operations importing semifinished parts to be assembled locally for export. Whereas Hanley et al. (2002) take a positive view of the absence of ties, in the dual economy model it is the very absence of connectedness between foreign and domestic firms that is the root of the problem (Comisso 1998). FDI leaves the domestic economy untouched, thereby maintaining underdevelopment. The absence of ties perpetuates a segregated economy, malevolent because its radical separation allows no positive influence across sectors. A case where foreign investors do not make network ties and where the networks of domestic firms grow only among themselves (Zysman and Schwartz 1998) would correspond to a radically segregated, dual economy in which FDI is overwhelmingly isolated and domestic firms are predominantly networked. 
American Journal of Sociology

With our data we can chart the proportions of the Hungarian mixed economy that are (1) networked and foreign, (2) networked and domestic, (3) isolated and foreign, and (4) isolated and domestic. ${ }^{4}$ The findings, reported for the entire period in a subsequent section below, are at odds with each of the three scenarios: by 2001, large firm capital was distributed across the four cells in roughly equal proportions. Domestic networks have not crowded out FDI, and multinationals have not eradicated the networks, but Hungary is also not a radically segregated dual economy.

This constellation of the macrostructure of ownership suggests that other processes are at play than those outlined in the scenarios above. The challenge, then, is to understand the processes whereby some foreign capital becomes integrated while other foreign capital becomes isolated, and how some network formations survive without foreign capital while other network formations develop with the participation of foreign investors. In short, what are the social processes that produced these macrostructural outcomes?

\section{A Social Sequence Approach to Foreign Embeddedness}

Our approach identifies processes that explain the integration of foreign investment in interorganizational ownership networks. We organize the analytical building blocks along two dimensions: topographical and temporal. Along the first dimension, we start from the insight of network analysis that network structures can differ in their topographical properties. Therefore, rather than simply identifying whether a given firm is embedded or not embedded in network ties, we probe for qualitative differences in types of embeddedness. Because we focus on network properties from the perspective of the individual firm, we are interested in variations in local network structures.

In locating the position of a given firm within distinctive local topographies, we distinguish structures that are more vertically organized with greater centralization from those that are more horizontally organized with greater cohesiveness. Recent empirical research on the shape of business networks across a variety of institutional settings has demonstrated that more cohesive, horizontal structures outperform more centralized, vertical forms. In the field of biotechnology, Powell and his coauthors (Powell et al. 2005) found that actors that are embedded in horizontal rather than hierarchical networks were more likely to be innovative. In her study of interorganizational networks in China, Keister (1998) found that nonhierarchical business groups were more buffered from uncer-

\footnotetext{
${ }^{4}$ In place of the former dichotomy of public vs. private, we redefine the term "mixed economy" along the foreign/domestic and networked/isolated dimensions.
} 
tainties and outperformed centralized groups. Similarly, in Russia, whereas defensive strategies of survival correspond to centralized business groups, entrepreneurial groups (often with foreign involvement) were more horizontal in structure (Huber and Wörgötter 1998).

The identification of the two prevalent forms of interenterprise ownership networks in the early part of the 1990s specifically pointed to the emergence of distinctively vertical and horizontal network structures (Stark 1996, 2001). The first form of recombinant property networks involved processes in which large state-owned or formerly state-owned enterprises spun off corporate satellites (some of which were still of considerable size, spinning off their own satellites), resulting in star-shaped networks with the very largest firms at the hubs. Along these vertical ties, firms shifted assets and liabilities in frequently shady arrangements that took advantage of shifting government policies (Voszka 1997). The second type of interenterprise ownership networks involved networks of greater density, resulting in decentered, more cohesive structures. Unlike the simple star-periphery structures, firms in these networks regrouped interdependent assets and restructured enterprises.

Just as domestic firms faced the uncertainties of postsocialism, so foreign actors faced uncertainties entering an emerging market. Our reading of the recent literature on foreign investment (Inkpen and Beamish 1997; Kogut 1988, 1991; Yiu and Makino 2002; Zaheer 1995) suggests that some foreign investors use ownership network ties to learn the rules of play, legitimize their presence, obtain local knowledge, and gain introduction into social networks by having a local partner. Forming a joint venture, for example, means that a foreign investor establishes a strong network tie (in the form of shared ownership) with a local firm to obtain legitimacy in the eyes of domestic economic actors, national policy makers, and local officials. Such network ties are potential avenues to obtain local knowledge, especially under conditions when the regulatory environment is untested, where domestic markets have culturally specific features (e.g., involving tastes or practices in advertising, marketing, packaging, etc.), or where basic infrastructural logistics (e.g., utilities, transportation, etc.) have locally idiosyncratic features. ${ }^{5}$

Following this earlier work on recombinant-property network structures (Stark 1996, 2001), we posit two distinctive patterns of network

\footnotetext{
${ }^{5}$ There are indications that the operation of business networks might be compatible with the structure and practices of multinational firms. To cope with challenges of organizing across geographical and cultural distances, multinationals are increasingly structured as networks (Ghoshal and Bartlett 1990; Morgan et al. 2001), seeking flexibility trough empowering subsidiaries and embedding in interorganizational relations (Buckley and Casson 1998). Hedlund (1993), e.g., suggests that multinational corporations are more heterarchical than hierarchical.
} 
formation in the extrication from state socialism: star-periphery structures and cohesive network structures. Following Kogut and others, we posit that a significant number of foreign investors will forge network ties with domestic partners. A key research question, then, is whether and how the vertical and horizontal variants of recombinant property (in networkanalytic terms, centralized vs. cohesive structures) figured in the strategies of foreign investors. Were foreign investors attracted to star-shaped networks because of their structural isomorphism to hierarchical supplier networks, or did they avoid these because of their historical origins as vehicles of asset stripping and liability management? Did foreign investors avoid entering cohesive and densely networked structures because they are cautious about the entanglements of such embeddedness, or did they prefer these structures because of their managerial entrepreneurialism?

Answering these questions requires that we add a temporal dimension to our topographical dimension. Foreign investment in Hungary was not immediately triggered by the collapse of communism; it was meager at the outset and developed as an incremental process across the entire epoch. To answer whether foreign owners opted for vertical or horizontal structures, or shunned both, we must therefore first examine whether either or both of these structures had any lasting durability to be available to foreign investment. By adding a temporal dimension to our analysis we can thus make more meaningful inferences about the relationship between network properties and organizing practices. In our study, we identify topography as a static property; we grasp structure as a temporal property identified as a sequence of network positions.

Building on recent efforts to bring dynamics into network analysis (Brudner and White 1997; Snijders 2001; Stuart 1998; Watts 1999; White 2004), we draw on sequence analysis, a recently developed research tool that makes it possible to study historical processes in an eventful way similar to historiography while retaining social scientific abstraction (Abbott and Hrycak 1990; Abbott 1995; Han and Moen 1999; Blair-Loy 1999; Stovel, Savage, and Bearman 1996; Giuffre 1999; Stovel 2001).

With attention to temporal sequencing, we can pose and answer questions about whether experiences and strategies in the early period of extrication from state socialism had consequences for later developments. This is especially important in Hungary where the challenges facing firms were not of the same kind throughout the time frame of our investigation. In particular, the political and institutional uncertainties of the early 1990s did not continue unabated throughout the entire epoch. Important decisions by the neoliberal socialist government during the middle of the decade had emphatic policy outcomes that largely brought ad hoc gov- 
ernment subsidies and bailouts to an end. ${ }^{6}$ With the institutionalization of regulatory policies of corporate governance, banking, and bankruptcy, for example, uncertainties in the institutional environment were replaced by the "normal" uncertainties of a market environment.

Given this changing historical context, we need to probe the durability of positions in vertical and horizontal topographies. A firm with a durable position in a cohesive structure $(\mathrm{C})$, for example, will evidence a relatively lengthy sequence in the same network position (C-C-C) across a number of years; the sequence of a firm remaining on the periphery $(\mathrm{P})$ of a vertical structure will register as P-P-P, and so on. Because of the environment changes during the epoch under investigation, we will be especially attentive to positional durability that begins during the earlier period and survives into the later period. Specifically, we expect to find a significant number of firms in durable positions in vertical and horizontal topographies, respectively, and we expect to find such durability extending across the 1995-96 boundary between the earlier and later periods. Moreover, we specifically hypothesize that sequence pathways characterized by durable positions in vertical structures will be significantly less likely to attract foreign owners than firms in durable positions in cohesive structures.

The reasoning behind our hypothesis starts with the observations of Powell, Keister, and others that less hierarchically organized business networks offer real performance benefits over vertically structured networks. Their multiplexity provides greater opportunities to adapt more flexibly to changes in the environment. Although vertical structures might be well adapted to a given environment, they are more prone to "lockin." That is, their centralized character increases the likelihood of temporally self-reinforcing processes in which patterns that were successful in an initial context persist even though there is no longer a performance advantage.

Foreign investors, we reason, are not averse to centralized, hierarchical structures. But, faced with two already established network structures, they will choose to gain ownership stakes in firms that have durable positions in the less hierarchical, more cohesive network topographies. This choice is especially likely in the Hungarian setting. More horizontally structured business networks can provide resources to cope with the challenges of the initial postsocialist period, and they can be more easily repurposed if and when the political, institutional, and business environ-

\footnotetext{
${ }^{6}$ The middle of the decade (1995-96) marked a key turning point in historical processes. A restrictive package in 1995 ended government bailouts and state paternalism (Stark and Bruszt 1998), and 1996 was the first year when GDP started growing after the postsocialist collapse.
} 
ment changes. Firms in positions within such cohesive topographies that endure across the time frame are, thus, likely to be strong candidates for foreign investment. Vertical structures might seem to offer ready avenues for straightforward command and control, but they are less likely to be repurposed. They will not be targets for foreign takeover. And the more they endure into the later period, the less attractive they will become, leading to yet further temporally self-reinforcing processes that result in a kind of network stasis with little foreign investment.

Thus, although we start from the notion that network ties are strategic resources for firms (Kogut, Shan, and Walker 1992), we do not assume that all firms have the same strategic orientations or that firms participate in network ties in the same way. Network properties vary not only across firms in network space but also across time. As firms make and break ties, they (and those around them in network space) can reproduce or reshape network properties. As they do, they produce distinctive sequences of network structures. That is, just as we will be attentive to variation in the specific shapes of the network properties in a given firm's network locale, so we will also be attentive to variation in social times. Network times and network spaces, separately and in their combination, are structuring-they enable and constrain how network ties can be deployed as resources.

We therefore posit that patterns of foreign investment can be explained not simply by the shape of network structures but by the structures of their sequencing. To test this proposition we develop an innovative synthesis of network analysis and sequence analysis.

\section{DATA AND TRENDS}

\section{Data Collection}

The data set we have assembled includes the complete ownership histories of the largest enterprises in Hungary during the period 1987-2001. We define a large firm as being in the annual ranking of the top 500 firms (based on revenue) in any of the years 1987-2001. Our inclusion rule results in a population of 1,843 firms. For a small country like Hungary, this population of firms accounts for more than a third of all employment, half of the GDP, and the overwhelming proportion of export revenues (Figyelö 2002). The comprehensiveness of our data set is unprecedented in the literature on changing ownership structures in a transforming economy. ${ }^{7}$

\footnotetext{
${ }^{7}$ Research projects on interenterprise ownership networks cover fewer companies, in less depth, over less time. Ferligoj, Prasnikar, and Pahor (2001), e.g., have analyzed
} 
Ownership data were transcribed by our research team directly from the 20 official courts of registry where Hungarian firms are obliged to register their owners. For each firm we collected the following: equity in thousands of Hungarian forints, the names of the firm's top 25 owners, and the percentage stake that each owner holds in the company. We also have information on the date when the firm was founded and the date of filing for bankruptcy, liquidation, or cessation for any reason, that is, the date when the file of the firm was closed at the registry court. Out of the 1,843 firms, 147 ownership files were unavailable or contained little or no information on ownership. Our final data set contains the full ownership histories of 1,696 enterprises. For any given firm in any given month in our data set we can precisely identify the owners and the percentage of the assets each holds.

We define a tie as an ownership stake that one enterprise in our population holds in another firm in the population. Our definition is restricted to direct ties (representing at least a $1 \%$ ownership stake) among the largest Hungarian enterprises. It does not include, for example, the numerous ownership stakes that these firms have in smaller companies. Nor do we report two firms as tied if they share a common owner, as in the more inclusive definitions of affiliation networks (Kogut and Walker 2001; Wasserman and Faust 1994). It follows that, in our population of firms, an ownership stake by the state or a foreign owner does not constitute an interorganizational tie. We have also coded owners by type, using the names of owners to classify four categories: state, Hungarian firm, Hungarian person, and foreign owner.

\section{The Changing Proportions of the Mixed Economy}

Our data set makes it possible to chart the changing configuration of the macrostructure of ownership across 15 years of Hungary's transforming and globalizing economy. Did domestic networks grow unchecked? Did foreign investment eradicate interenterprise ownership ties? Or is Hungary a dual economy, segregated into two segments of domestically networked and foreign isolates?

To gain a picture of the evolving shape of Hungary's mixed economy,

the networks of the largest Slovenian companies based on ownership and board interlock ties in 1997 and 2000. However, their analysis was cross-sectional, and their sample was limited only to the top 150 firms in each of the two years in their study. Both of these studies were cross-sectional. Several studies outside the East European region examine panel data. Kogut and Walker (2001), e.g., study ties among 550 of the largest firms in the German economy, 1994-97. Keister (2001) examines 535 Chinese firms, 1988-96. Her data involve 40 named and already identified business groups in which the location of a given firm in a given business group is fixed by lists from 1985 . 
for each year from 1987 to 2001 we computed the proportion of large firm capital in four categories: (1) firms that are isolated and domestically owned, (2) firms that are isolated and have significant foreign ownership, (3) firms with an interenterprise ownership tie and that are domestically owned, and (4) firms with an interenterprise ownership tie and significant foreign ownership. A significant foreign owner, in our definition, is a clearly dominant owner or, at least, a coalition partner in ownership (see app. A for definitions).

Figure 1 presents the broad contours of the changing shape of Hungary's mixed economy across the period under study. It illustrates that alternative scenarios were open possibilities from 1991. Selective extrapolation from early trends in different categories could yield very different expected outcomes. For example, between 1989 and 1991, the networkeddomestic category increased from $27 \%$ to $57 \%$. Selective extrapolation from this dramatic growth could have suggested that networked-domestic firms would crowd out other forms of property including foreign ownership, perhaps along the antidevelopmental lines of the Russian economy (Burawoy and Krotov 1992; Johnson 1997). Similarly, focusing on the growth of the isolated foreign category, nearly doubling between 1989 $(8 \%)$ to 1990 ( $15 \%$ of large firm capitalization), one could have selectively extrapolated an economy dominated by foreigners and the extinction of domestic network forms of property (Hanley et al. 2002). The high rate of growth of both the isolated-foreign and networked-domestic categories could have encouraged predictions about an emerging segregated dual economy (Comisso 1998).

Our findings indicate that each of the scenarios would fail to account for actual developments. In a segregated dual economy, the overwhelming majority of firm capital would be in two categories: networked domestic and isolated foreign. But Hungary is not a segregated dual economy, ${ }^{8}$ and yet neither is it an economy dominated by isolates, nor by the networked domestic. In 2001, the distribution of capital among the four categories was the following: isolated domestic, $18 \%$; isolated foreign, $29 \%$; networked domestic, $26 \%$; and networked foreign, $26 \%$. Although the isolated foreign-owned firms constitute the largest category, this segment of the mixed economy contains only three percentage points more capital than the foreign-owned networked category of firms.

Although the proportion of the economy that participates in interen-

\footnotetext{
${ }^{8}$ We tested the hypothesis that the foreign-owned and the domestically owned segments are not connected by network ties. Chi-square tests of the distribution of ties between and within these segments are insignificant (the smallest $P$-value for any year is .419). Ties between foreign-owned and domestically owned firms are just as likely as ties within these segments.
} 


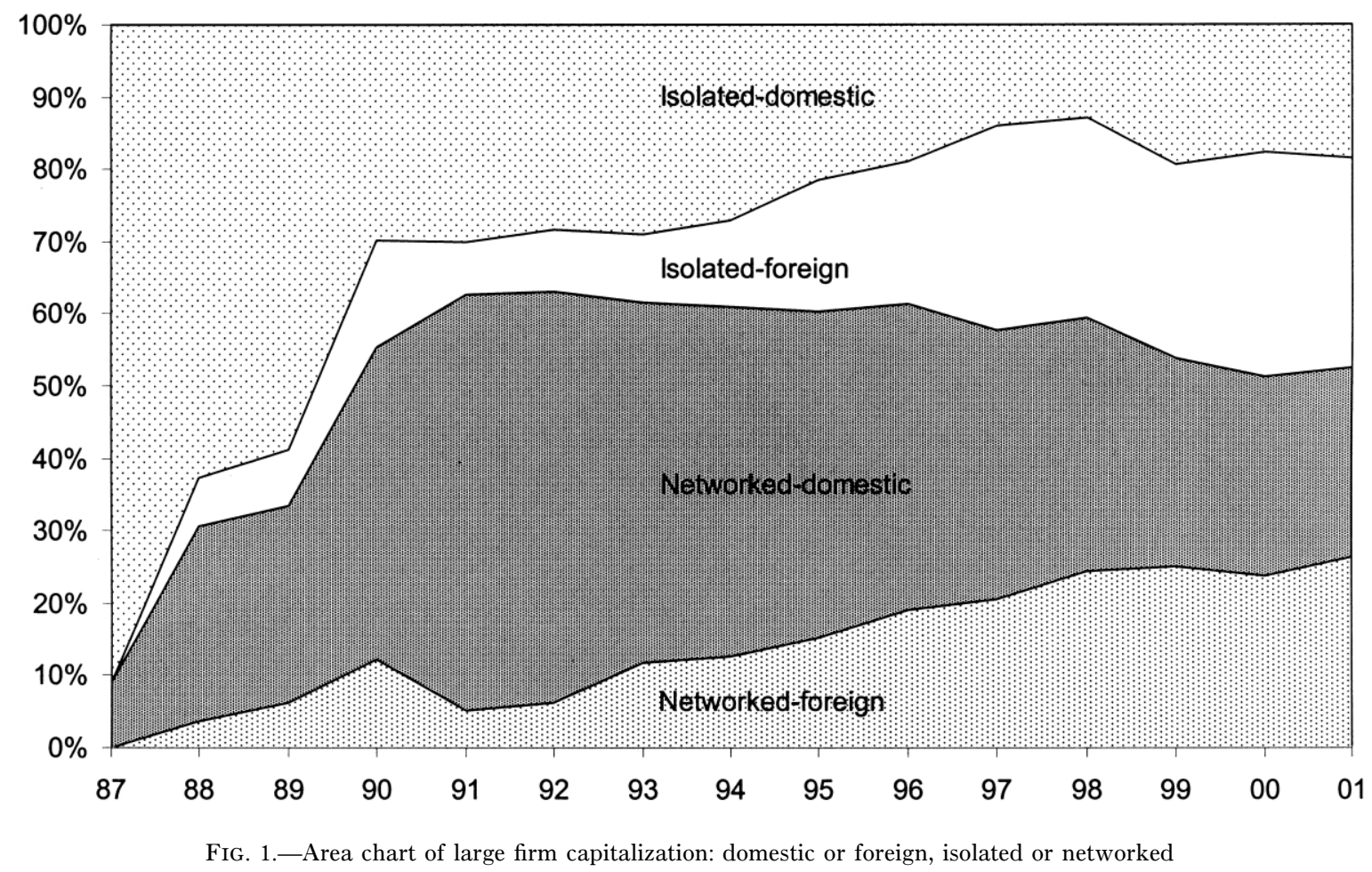


American Journal of Sociology

terprise ownership ties becomes smaller, it does not-in contrast to the arguments of the transition school—dissolve. By the end of our study, $52 \%$ of capitalization was in firms with at least one interorganizational ownership tie with another large firm in the sample. Moreover, there is evidence indicating that the strength of a given tie has increased. In the first years of our period an average network tie represented a $20 \%$ ownership stake in a company. By 2001, the average tie strength is $36 \%$, suggesting the consolidation rather than the dissolution of the network.

Unanticipated and unexplained by any of the three competing scenarios is the steady growth, between 1991 and 2001, of the networked-foreign category, eventually comprising half of the networked capital.

\section{SOCIAL SEQUENCE ANALYSIS OF NETWORK EVOLUTION}

Studies of property transformation in the postsocialist setting typically focus on broad changes in the structure of property in terms of ownership categories such as state ownership, private ownership, foreign ownership, and the like. Although our macrostructural model adopted a similarly categorical approach, the microprocessual models that we develop below examine the structure of property in relational terms, focusing on its network properties. Whereas much of the recent work on network dynamics has focused on topographic properties of the global network, in particular its properties of connectedness, we start from the perspective of the individual firm and analyze its network position within a field of local action.

To isolate the distinctive processes and the variable social times that might be masked by system-level investigations, we identify patterned variation in sequences of events in the lives of firms. These events are changes in the configuration of the network properties of its local field of action. To proceed, we identify the empirically observable types of local embeddedness and elaborate the methods used to cluster sequences into typical pathways through that network space.

\section{Identifying Local Network Positions}

In analyzing the evolution of interenterprise ownership ties in Hungary, we study topography at a socially meaningful level of action. Ownership networks, we reason, differ from networks of flow. In such networks, where electricity, rumors, or contagious disease can spread along any number of steps, the most important task is to understand the global configuration of the network, the redundancy of connecting paths, and the overall structure of reachability. Ownership networks, however, have 
a shorter range (path distance beyond which there is no interrelatedness). Path distances beyond two steps (the owners of owners) have little importance: whereas the owner of the owner can be important, the owner of the owner of the owner has little influence in the life of a postsocialist firm. Therefore, we focus on the shapes of local network configurations, building up from ties of the focal firm and of its near network neighbors. Accordingly, we ignore the directionality of ties and use the symmetrized ownership network.

In defining local network topographies we do not posit particular shapes or configurations in advance. Instead, we begin by defining the dimensions along which focal firms' network topographies can vary. Starting from a set of elemental dimensions and applying a clustering algorithm, we identify a finite set of distinctive local network properties. For a given firm, for any year in which it existed, we can then code its position within a local topography. In place of the topographic properties of the global network for each of the 15 years in our study, our analysis is conducted on 18,073 cases (i.e., one network position for each firm in every year that it existed). The unit of analysis is, thus, the local network position of a given firm in a given year.

We define dimensions of local network topographies in line with findings of the literature on interorganizational networks and business groups. Granovetter (1994), for example, identifies the key structural dimensions of interorganizational networks as, first of all, the size of a firm's network as well as the configuration of its ties, especially the level of cohesion and the degree of centralization. These insights informed empirical research on the shape of business networks. As Powell et al. (2005) found for biotechnology, Keister (1998) found for China, and Huber and Wörgötter (1998) found for Russia, vertical versus horizontal structure is a key dimension of network organizing.

To capture these salient features of business networks, we define four dimensions along which local network topographies can vary. To capture size, we define the first dimension as (1) the number of alters in the focal firm's ego network. To capture the structural configurations of ties, we define three additional dimensions: (2) the average size of all alters' ego networks, (3) the cohesion of the focal firm's network, and (4) the average number of cohesive paths in all alters' ego networks.

Measuring cohesion in ownership networks (dimensions 3 and 4) is less straightforward than measuring size (dimensions 1 and 2). One starting point would be to use a clustering coefficient that measures the proportion of alters connected to one another in ego's network (Watts 1999; Davis 1970). The assumption of this measure is that the basis of cohesion is triadic closure as, for example, when two friends of a third person become friends of each other. However, an ownership network is different from 
a friendship network: while closed triads are uncommon, firms in cohesive ownership networks are often tied in linked quadruplets (four firms connected by at most two-step paths). ${ }^{9}$ Thus, we take both direct ties (onestep paths) and two-step paths into account in estimating the number of alters connected. ${ }^{10}$

Emphatically, it is not the individual dimensions but the patterns across them that define the discrete shape of a given topography. Therefore, after measuring these four dimensions for each of the firm-years in our population, we run Ward hierarchical cluster analysis (Ward 1963) on those 18,073 cases to identify patterns in the data. This cluster analysis groups cases according to their similarity across the four dimensions.

Table 1 presents the seven typical local network topographies derived by the cluster analysis: isolate, dyad, small star periphery, large star periphery, star center, cohesive cluster, and strongly cohesive group. ${ }^{11}$ In the fourth column of table 1 we report, for each topography, the mean scores along our four dimensions. There we see, for example, that although the number of ties in the ego networks of small star periphery and large star periphery structures are nearly the same, the mean size of their alters' networks is markedly different. ${ }^{12}$ Star centers and star peripheries, of course, lack cohesion, but the cluster analysis further distinguishes a topography that is cohesive from one that has extraordinarily strong group cohesion.

\footnotetext{
${ }^{9}$ Ownership networks are, moreover, typically sparser than friendship networks. For a discussion see Kogut and Walker (2001).

${ }^{10}$ Commonly used clustering coefficients (Davis 1970; Watts 1999) record the proportion of alters that are connected. We decided to use the number rather than the proportion of alters connected. The reason for this is that cohesion enters into our cluster analysis alongside size-measured as the number of alters. Using the proportion of connected alters as the measure of cohesion in this cluster analysis would seriously underweight this dimension.

${ }^{11}$ We tested the hypothesis that network transformation in this case is a product of a merely random process. This hypothesis is a plausible one, especially given the pace of institutional transformation. Firms might resort to forming ad hoc ties when pressed to hedge against radical uncertainties. Similarly, network ties might be cut at random when, e.g., a new owner appears. To evaluate the random network change hypothesis we ran simulations from which we conclude that the observed changes in network ties are not products of a random process. (See app. B for details.)

${ }^{12}$ The break point between these two topographies was not determined a priori. Instead, it was empirically observable in the data. The distribution of star sizes in our data is bimodal with the two modal types represented by the two clusters (small star periphery and large star periphery).
} 
TABLE 1

Local Network Positions

\begin{tabular}{|c|c|c|c|c|}
\hline $\begin{array}{l}\text { Network } \\
\text { Position }\end{array}$ & $N$ & $\begin{array}{l}\text { Percentage of } \\
\text { Nonisolate }\end{array}$ & $\begin{array}{c}\text { Means of Ego } \\
\text { Network } \\
\text { Statistics }\end{array}$ & $\begin{array}{l}\text { Graph } \\
\text { Illustration }^{\mathrm{a}}\end{array}$ \\
\hline I. Isolate & 12,378 & & $\begin{array}{l}\text { Size: } 0.00 \\
\text { Alters' size: } 0.00 \\
\text { Cohesion: } 0.00 \\
\text { Alters' cohesion: } 0.00\end{array}$ & 0 \\
\hline D. Dyad member & 1,260 & 22.12 & $\begin{array}{l}\text { Size: } 1.00 \\
\text { Alters' size: } 1.00 \\
\text { Cohesion: } 0.00 \\
\text { Alters' cohesion: } 0.00\end{array}$ & \\
\hline P. Small star periphery & 1,985 & 34.86 & $\begin{array}{l}\text { Size: } 1.22 \\
\text { Alters' size: } 3.34 \\
\text { Cohesion: } 0.00 \\
\text { Alters' cohesion: } 0.00\end{array}$ & \\
\hline L. Large star periphery & 280 & 4.92 & $\begin{array}{l}\text { Size: } 1.05 \\
\text { Alters' size: } 12.10 \\
\text { Cohesion: } 0.00 \\
\text { Alters' cohesion: } 0.00\end{array}$ & \\
\hline S. Star center & 543 & 9.53 & $\begin{array}{l}\text { Size: } 3.37 \\
\text { Alters' size: } 1.35 \\
\text { Cohesion: } 0.00 \\
\text { Alters' cohesion: } 0.00\end{array}$ & \\
\hline $\begin{array}{l}\text { C. Cohesive cluster } \\
\text { member }\end{array}$ & 899 & 15.79 & $\begin{array}{l}\text { Size: } 2.84 \\
\text { Alters' size: } 6.82 \\
\text { Cohesion: } 0.46 \\
\text { Alters' cohesion: } 1.20\end{array}$ & \\
\hline $\begin{array}{l}\text { G. Strongly cohesive group } \\
\text { member }\end{array}$ & 728 & 12.78 & $\begin{array}{l}\text { Size: } 2.71 \\
\text { Alters' size: } 9.91 \\
\text { Cohesion: } 2.40 \\
\text { Alters' cohesion: } 8.55\end{array}$ & \\
\hline Total & 18,073 & 100.00 & & \\
\hline
\end{tabular}

${ }^{\mathrm{a}}$ White node indicates local network position in graph illustrations.

Optimal Matching Analysis of Network Sequences

The particular type of embeddedness for any given firm, in any given year, is now categorized as one of the seven positions. The network history of a firm can now be represented as a sequence of topographies. Figure 2 is an example of a firm's history as it moves from one type of embeddedness to another.

This firm starts as an isolate. After three years, it becomes the periphery of a small star. In 1992 the topography of the firm's local network is a cohesive cluster, and after three years, these network ties are transformed into a strongly cohesive group. In 1998 the firm becomes a small star 


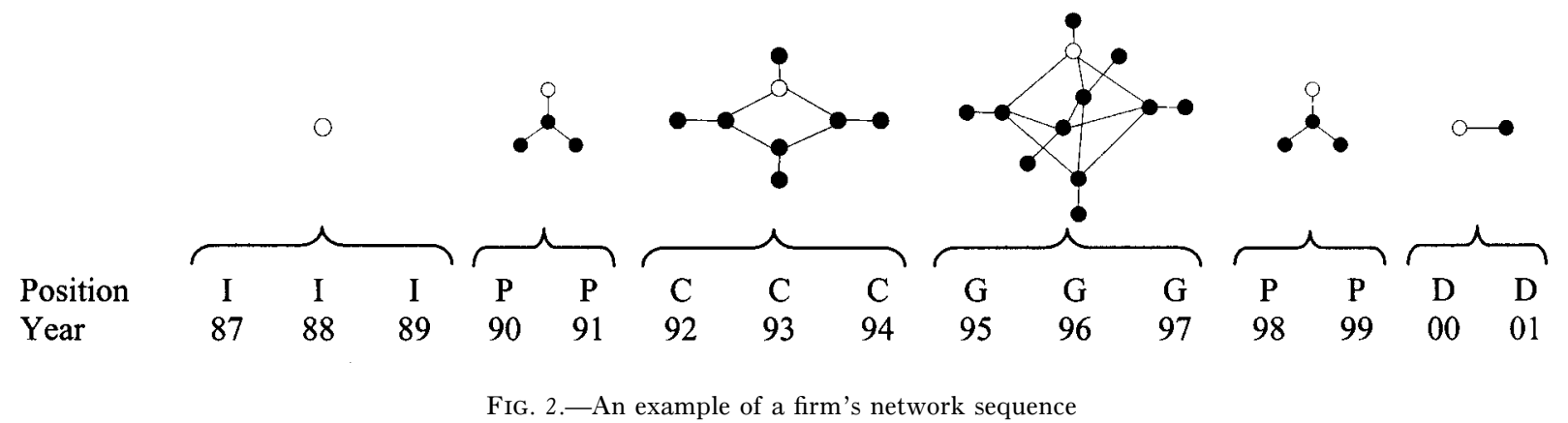


periphery again. At the end of the period, from 2000, the star shrinks into a dyad.

On this basis, we have 1,696 such network histories-sequences of positions - for each of the firms in our population. Some firms' histories, of course, are likely to resemble each other (not because they are tied to each other but because they have similar sequences of network positioning) while differing from others. Using an optimal matching algorithm modified from the analysis of gene sequencing, we construct a matrix of pairwise distances between each of the sequences.

Optimal matching of sequences is a method that historical sociology borrowed from natural sciences. The use of optimal matching in the natural sciences typically does not involve temporality; instead, the sequences are typically spatial. One major area in natural sciences for the use of optimal matching is DNA analysis. DNA molecules are considered to be very similar even when large chunks of the molecular sequence are in reverse order (Sankoff and Kruskal 1999). Unlike measures based on vector similarities, optimal matching has some advantages for historical application, but it has been justifiably criticized by Wu (2000) and others (Levine 2000) for its lack of sensitivity to the directionality of time. For example, a firm that is an isolate for eight years and then becomes a small star periphery in 1995 for the next seven years represents a radically different career compared to a firm that is a small star periphery for the first seven years and then becomes an isolate in 1995. Because the default optimal matching algorithm would group these two cases as similar, we make adjustments to the parameters of the method to maximize temporal sensitivity. (See app. C for details about the adjusted parameters used in our optimal matching analysis.)

We first use optimal matching to find the distance of each sequence from all others (Rohver and Pötter 2002). To the resulting matrix we then apply hierarchical clustering that groups sequences so that within-cluster distances are as low as possible and between-cluster distances are high. From among the commonly used clustering methods, we applied Ward's method as the best-fitting clustering solution. ${ }^{13}$ The combination of these two algorithms, not unlike the concept of structural equivalence in social network analysis, yields sequential equivalence (Han and Moen 1999, p. 204).

${ }^{13}$ We compare the fit of clustering derived from five algorithms: single link, average link, complete link, Ward (increase in sum of squares) hierarchical clustering, and CONCOR divisive clustering. The $R^{2}$ of a 13-cluster grouping by these methods are $.014, .144, .349, .590$, and .411 , correspondingly. Thus we use Ward's method (Wishart 2003 ) as the one that best fits our data to identify groups of similar sequences. The clusters that we identify represent a meaningful reduction of the data: the $t$-test of comparing within-cluster distances to between-cluster distances is -231.300 . 
Using these methods, our social sequence analysis yields 12 distinctive patterns of sequences, or pathways, through the space of local network topographies. Reducing 1,696 firm network histories to 12 pathways, we explain $59 \%$ of the variance in intersequence distances, indicating that a small number of pathways is a suitable representation of network evolution.

\section{Sequence Pathways and Foreign Investment}

The resulting 12 pathways, grouped as five broad types of pathways, are presented in table 2, briefly summarized here, and more fully elaborated later. The first two broad types involve the forms of recombinant property-the star-shaped spin-off structures and the cohesive groupings, respectively. The third type of pathway is marked by start-up firms. Beginning as small star peripheries or dyads, ties are later broken, and these firms typically, though not uniformly, exhibit sequences leading toward isolation. The fourth type shows an entirely different sequence. These are pathways in which network formation occurs after the period of greatest institutional uncertainty. Moreover, unlike the pathways in the third family, these ties do not dissipate. In fact, they are not only durable but are evolving from dyads to more complex network topographies. The fifth type comprises firms that are isolates across the entire period. Firms in this final pathway are characterized by a later start and are significantly smaller than firms in other pathways.

Table 2 presents, for each of the pathways, the sequence of network positions that best represents firm histories in that pathway. (See app. D for details on identifying representative sequences.) Cell entries (I, D, P, $\mathrm{L}, \mathrm{S}, \mathrm{C}$, and G) correspond to the local network topographies defined in table 1. Enterprise histories are presented in five groups of pathways according to broad similarities in sequence patterns. The number of firms in each pathway is one way to measure their prevalence, but as a better indication of economic importance, we also list the share of each pathway in the total capitalization of the large firm population in 2001. Recalling the macrostructure of Hungary's mixed economy represented in figure 1, in which the growing percentage of the networked-foreign category is the most striking feature that was neither anticipated nor explained by the three competing scenarios, table 2 also reports each pathway's share of networked-foreign capital at the close of our study.

To test our proposition that foreign ownership can be explained not simply by the shape of network structures but by the sequencing of network positions, we use logistic regression to analyze the statistical association between sequence pathways and sizable foreign ownership in 2001 . The definition of our dependent variable, sizable foreign ownership, is 
TABLE 2

Pathways' Typical Sequences of Network Positions

\begin{tabular}{|c|c|c|c|c|c|c|c|c|c|c|c|c|c|c|c|c|c|c|}
\hline \multirow[b]{2}{*}{ Pathways } & \multirow[b]{2}{*}{$N$} & \multicolumn{15}{|c|}{ YEAR $^{a}$} & \multicolumn{2}{|c|}{$\begin{array}{c}\text { SHARE IN CATE- } \\
\text { GORIES OF CAPI- } \\
\text { TAL IN } 2001 \\
\end{array}$} \\
\hline & & 1987 & 1988 & 1989 & 1990 & 1991 & 1992 & 1993 & 1994 & 1995 & 1996 & 1997 & 1998 & 1999 & 2000 & 2001 & All & $\begin{array}{l}\text { Networked } \\
\text { Foreign }\end{array}$ \\
\hline \multicolumn{19}{|l|}{ Star-periphery recombinants: } \\
\hline $1 \ldots \ldots \ldots \ldots+\cdots \cdots$ & 34 & I & I & I & $\mathrm{S}$ & $\mathrm{S}$ & $\mathrm{S}$ & $\mathrm{S}$ & $\mathrm{S}$ & $\mathrm{S}$ & $\mathrm{S}$ & $\mathrm{S}$ & $\mathrm{S}$ & $\mathrm{S}$ & $\mathrm{S}$ & $\mathrm{S}$ & 7.1 & 1.4 \\
\hline $2 \ldots \ldots \ldots \ldots \ldots \ldots$ & 106 & & & & $\mathrm{P}$ & $\mathrm{P}$ & $\mathrm{P}$ & $\mathrm{P}$ & $\mathrm{P}$ & $\mathrm{P}$ & $\mathrm{P}$ & $\mathrm{P}$ & $\mathrm{P}$ & $\mathrm{P}$ & $\mathrm{P}$ & $\mathrm{P}$ & 3.8 & 3.0 \\
\hline \multicolumn{19}{|l|}{ Cohesive recombinants: } \\
\hline З & 70 & & I & I & $\mathrm{P}^{*}$ & $\mathrm{P}$ & $\mathrm{C}$ & $\mathrm{C}^{*}$ & $\mathrm{C}$ & $\mathrm{C}$ & C & C & $\mathrm{C}$ & $\mathrm{P}$ & $\mathrm{P}$ & $\mathrm{P}$ & 18.2 & 36.1 \\
\hline $4 \ldots \ldots \ldots \ldots \ldots \ldots \ldots \ldots$ & 44 & & & $\mathrm{C}$ & $\mathrm{C}$ & $\mathrm{C}$ & G & G & G & $\mathrm{G}^{*}$ & G & $\mathrm{C}$ & $\mathrm{C}$ & $\mathrm{C}$ & $\mathrm{C}$ & $\mathrm{C}$ & 4.9 & 12.2 \\
\hline 5 다. & 65 & & & $\mathrm{C}$ & $\mathrm{C}$ & $\mathrm{C}$ & G & G & G & G & G & $\mathrm{G}^{*}$ & G & I & I & I & 3.6 & 0.6 \\
\hline …............... & 56 & I & I & I & I & I & I & I & I & $\mathrm{L}$ & $\mathrm{L}$ & $\mathrm{C}$ & $\mathrm{C}$ & G & G & G & 7.0 & 6.7 \\
\hline \multicolumn{19}{|l|}{ Start-ups: } \\
\hline & 63 & & & $\mathrm{P}$ & $\mathrm{P}^{*}$ & $\mathrm{P}$ & $\mathrm{P}$ & $\mathrm{P}$ & $\mathrm{P}$ & $\mathrm{P}$ & I & I & I & I & I & I & 3.4 & 0.0 \\
\hline 8 & 97 & & & & $\mathrm{D}$ & $\mathrm{D}^{*}$ & $\mathrm{D}$ & $\mathrm{D}^{*}$ & I & I & $\mathrm{I}^{*}$ & I & I & I & I & I & 4.2 & 0.3 \\
\hline 9 & 70 & & & & $\mathrm{P}^{*}$ & $\mathrm{P}$ & $\mathrm{P}$ & $\mathrm{P}$ & $\mathrm{P}$ & $\mathrm{D}$ & $\mathrm{D}^{*}$ & $\mathrm{D}$ & $\mathrm{D}$ & $\mathrm{D}$ & $\mathrm{D}$ & $\mathrm{D}$ & 3.9 & 8.6 \\
\hline \multicolumn{19}{|l|}{ Second-wave networks: } \\
\hline 10 & 136 & I & I & I & I & I & I & I & I & $\mathrm{D}^{*}$ & $\mathrm{D}$ & $\mathrm{D}$ & $\mathrm{D}$ & $\mathrm{P}$ & $\mathrm{P}$ & $\mathrm{P}^{*}$ & 9.1 & 21.6 \\
\hline 11 . & 101 & & & & & & & & & & & $\mathrm{D}^{*}$ & $\mathrm{D}^{*}$ & $\mathrm{P}$ & $\mathrm{P}$ & $\mathrm{P}$ & 3.3 & 8.7 \\
\hline \multicolumn{19}{|l|}{ Isolates: } \\
\hline 12 & 854 & & & & & & I & I & I & I & I & $I^{*}$ & I & I & I & I & 30.7 & 0.0 \\
\hline Total . & 1,696 & & & & & & & & & & & & & & & & 100.0 & 100.0 \\
\hline
\end{tabular}


the same here as the previous usage. A sizable foreign owner is a clearly dominant owner, or, at least, a coalition partner in ownership. (See app. A for definitions and procedures.)

The first independent variables in our model are the network pathways identified through optimal matching procedures, with the isolate pathway as the reference category. We control for three further attributes of firms, which we expect to be associated with foreign ownership. To rule out that differences between pathways are simply a function of their industrial composition, we first control for branch of industry. Our model uses 11 industry categories: agriculture, food industry, energy and mining, chemical industry, heavy industry, light industry and textiles, construction, wholesale, retail, and finance, with services and transportation as the reference category. Because foreign ownership might be associated with the latest topography rather than the sequence of positions, we, second, control for local network positions in 2001, with isolation as the reference category. If the inclusion of these variables leads to the loss of significance of pathway coefficients, then our arguments about sequencing become questionable. To rule out that foreign ownership in 2001 is simply a function of early foreign investment, we, third, control for whether there was sizable foreign ownership in a given firm in 1990. In line with how figure 1 was constructed, in the logistic regression analysis, we weight firms by their capitalization.

As model 1 in table 3 indicates, our sequence pathways are strongly associated with foreign ownership. This statistical association holds and, in fact without exception, becomes stronger when the control variables are included in model 2. Branch of industry and local network position at the end of the study are contributing factors in explaining foreign ownership. The significant association between early foreign ownership and sizable foreign ownership in 2001 does suggest that foreign investment displays considerable stickiness. But the statistical association between pathways and foreign ownership remains robust even when these controls are introduced.

Turning to the sequence pathways: as we saw in the detailed representations of typical sequences in table 2, one of the strongest findings of our optimal matching analysis is the persistence of the two forms of recombinant property. But if each of the forms are robust structures that survived the entire epoch, table 3 indicates they are strikingly different in terms of their likelihood to attract considerable foreign investment. Pathways in which spin-offs locked into star-periphery structures enlisted hardly any foreign investment. By contrast, two of the pathways with lengthy sequences of cohesion spanning the 1995-96 boundary were likely to have sizable foreign ownership in 2001. (Differences across the pathways in each of the families are elaborated below.) 
TABLE 3

Sizable Foreign Ownership in 2001: Logistic Regression Estimates

\begin{tabular}{|c|c|c|}
\hline \multirow[b]{2}{*}{ INDEPENDENT VARIABLES } & \multicolumn{2}{|c|}{$\begin{array}{l}\text { SiZABLE FoREIGN OWNERSHIP } \\
\text { IN } 2001(\text { yes }=1)\end{array}$} \\
\hline & 1 & 2 \\
\hline \multicolumn{3}{|l|}{ Pathways: ${ }^{a}$} \\
\hline \multicolumn{3}{|l|}{ Star-periphery recombinants: } \\
\hline 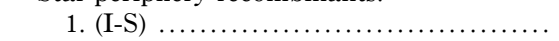 & $-5.513^{* *}$ & $-5.781 * *$ \\
\hline 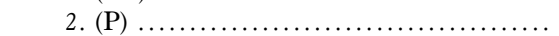 & $-.422 *$ & $-.785^{*}$ \\
\hline \multicolumn{3}{|l|}{ Cohesive recombinants: } \\
\hline 3. (I-P-C-P) & -.065 & .622 \\
\hline 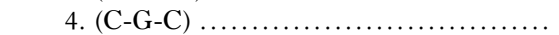 & $.485^{*}$ & $1.112 * *$ \\
\hline 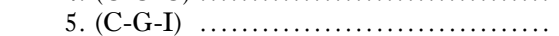 & $1.327 * *$ & $2.047 * *$ \\
\hline 6. (I-L-C-G) & $-1.091 * *$ & $-1.341 * *$ \\
\hline \multicolumn{3}{|l|}{ Start-ups: } \\
\hline 7. $(\mathrm{P}-\mathrm{I})$ & $1.565 * *$ & $2.087 * *$ \\
\hline 8. (D-I) & .342 & $1.076 * *$ \\
\hline 9. (P-D) .......... & $1.419 * *$ & $2.756 * *$ \\
\hline \multicolumn{3}{|l|}{ Second-wave networks: } \\
\hline 10. (I-D-P) & $1.218^{* *}$ & $1.752 * *$ \\
\hline 11. (D-P) .. & $1.184 * *$ & $1.717 * *$ \\
\hline \multicolumn{3}{|l|}{ Industry: } \\
\hline Agriculture & & $-2.973 * *$ \\
\hline Food ........ & & $2.779 * *$ \\
\hline Energy and mining . & & $.996 * *$ \\
\hline 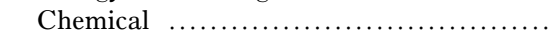 & & $4.756 * *$ \\
\hline Heavy industry & & $1.768 * *$ \\
\hline Light industry and textile $\ldots \ldots \ldots \ldots$ & & .378 \\
\hline Construction $\ldots \ldots \ldots \ldots \ldots \ldots \ldots \ldots$ & & -.517 \\
\hline Wholesale ............................... & & .391 \\
\hline Retail & & $3.695 * *$ \\
\hline (....................... & & .359 \\
\hline \multicolumn{3}{|l|}{ Local network position in $2001:^{c}$} \\
\hline $\mathrm{D}$ (dyad member) ......... & & -.720 \\
\hline $\mathrm{P}$ (small star periphery) $\ldots \ldots \ldots \ldots \ldots \ldots \ldots$ & & -.097 \\
\hline L (large star periphery) $\ldots \ldots \ldots \ldots \ldots \ldots \ldots$ & & $1.892 * *$ \\
\hline 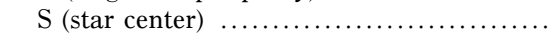 & & .140 \\
\hline $\mathrm{C}$ (cohesive cluster member) ............. & & -.039 \\
\hline $\mathrm{G}$ (strongly cohesive group member) ...... & & $-2.737 * *$ \\
\hline Early foreign ownership $(1990) \ldots \ldots \ldots \ldots \ldots$ & & $4.326 * *$ \\
\hline 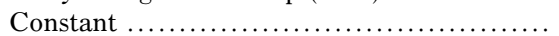 & $.205^{* *}$ & $-.935 * *$ \\
\hline 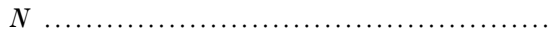 & 1,286 & 1,286 \\
\hline ............. & $1,709.03$ & $1,326.78$ \\
\hline$R^{2} \ldots \ldots$ & .249 & .498 \\
\hline$\%$ correctly classified ... & 66.7 & 74.8 \\
\hline 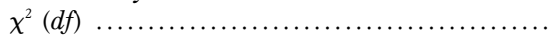 & $302.45(11)$ & $684.71(28)$ \\
\hline 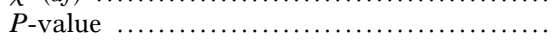 & .000 & .000 \\
\hline
\end{tabular}


By themselves, the pathways of the third type might suggest that foreign ownership is associated with the dissolution of network ties. However, the pathways in the fourth type, in which we find a second wave of network formation in the period of institutional stabilization of the market economy, are also significantly more likely than the isolate pathway to involve sizable foreign ownership in 2001. These recently emerging new networks involving foreign owners become organized in small starperiphery structures. As topographies, they are not dissimilar to those of the first type, shunned by foreign investors. The contrast exemplifies that sequence rather than contemporaneous topography matters in explaining foreign ownership. In the subsections below we discuss these findings in greater detail with attention to the coevolution of network formation and foreign investment.

Spin-off star-periphery recombinants in a process of lock-in.-The 140 firms in our first group of two pathways have distinctive histories of nearly continuous locations in star-periphery topographies. The typical sequences are lengthy episodes either as star centers (S-S-S-S) or as small star peripheries (P-P-P-P). These pathways indicate the process by which stateowned firms spun off corporate satellites in the period of regime change and its immediate aftermath: by 1990, most of the firms in pathways 1 and 2 were stars or the peripheries of stars.

During the period of high institutional uncertainty in the early years of postsocialism, the firms in this first group of pathways follow courses consistent with playing the game of asset-liability management, spinning off satellites, spreading risk, and shedding risk by shifting assets and liabilities among them in attempts to take advantage of state-sponsored programs of debt forgiveness. Of course, not every firm (in the whole population) that starts its network career as a small star or in its periphery stays in that position. Some firms will break off (perhaps as dyads), be sold off (perhaps becoming isolates), or become involved in local networks with more cohesion. If they did, their network histories will show different sequences, and they would not have been clustered in this group of pathways. The point is that the firms in these two pathways did not break off, were not sold off, and, for the most part, did not become involved in more cohesive ties. That is, in these two pathways we see clear evidence of path dependency: having established a pattern of network ties during the period of institutional uncertainty, these firms locked into patterns that endured throughout the epoch even after the organizational environment changed (Arthur 1989; Mahoney 2000).

How did they fare? They survived. Did they thrive? By 2001, these 140 firms (i.e., about $8 \%$ of the enterprises in the large firm population) accounted for $10.9 \%$ of the total capitalization in that population. They are a modest but not a negligible segment of the Hungarian economy. 
The Hungarian economy seems to have room even for path-dependent roads. Did they attract foreign investment? Scarcely. Our findings suggest that foreign investors shunned these firms. Created in the shadow of the state and likely facilitating some shady maneuverings, these ties buffered firms from uncertainty during the extrication from state socialism. But, locked into these path-dependent ties, the firms in these pathways were locked out from participating with foreign investors.

Cohesive recombinants repurposed.-Taken by itself, our first group of pathways might suggest evidence supporting the strong version of the dual economy thesis with domestic firms networked and foreign firms isolated. But that notion is quickly dispelled upon examining the network histories of firms in the second group of pathways. Here we find cohesive structures that were able to attract foreign investors.

The first part of the network history of the firms in pathway 3, like those in the first group, indicate the process of spin-offs and state-owned conglomerates. As separate firms were formed out of the divisions and workshops of the state-owned enterprises, the size of the ownership stars grew. But, unlike the pathways in the first group, the firms in this pathway establish cohesion. This is maintained until 1998 when foreign owners begin consolidating their subsidiaries.

The firms in pathway 4 are involved in cohesive structures from the moment of their founding. That is, at the outset of their appearance as a corporate form they are already participating in dense ownership networks. This cohesion, moreover, increases: between 1992 and 1997, the overwhelming majority of the firms are members of strongly cohesive groups. This strong cohesion, however, is not a barrier to foreign investors: by 2001 , the firms in this pathway represent $4.9 \%$ of overall capitalization but constitute $12.2 \%$ of networked-foreign capitalization.

The enterprises in these two pathways correspond to firms identified (Stark 1996) as parts of characteristically recombinant property networks. Based on comparable data collected from registry courts in 1994, complemented by ethnographic research in 1993-94, this earlier research suggested that, for some of these firms, beyond maneuvering in the shadow of the state, these network ties were facilitating an active restructuring of assets. That is, recombinant property could involve creative recognition of resources and their recombination along network lines. From this research conducted during a period of extraordinarily rapid change, it remained an open question whether these network forms of property represented merely a snapshot of a fleeting process. Our findings, based on data gathered across 15 years, indicate that this organizational form was not limited to the years of turbulent transformation, that it has been robust, and, moreover, that it has been open to a considerable amount of 
foreign investment. By 2001, almost one-quarter of the foreign-controlled capitalization in Hungary was in enterprises in these two pathways.

Comparing the two processes involving recombinant property forms, we found that foreign investors clearly preferred the durably cohesive structures, reaching into the cohesive groups where restructuring of assets was already taking place. Whereas the more vertical, star-periphery structures locked in, the more horizontal, collaborative, cohesive structures could be repurposed, buffering against the uncertainties of postsocialism in the early period and facilitating further restructuring with foreign participation in the later period. ${ }^{14}$ In contrast to the vertical structures in which the relationship of peripheral firms was dependent on star centers and insulated from each other, in the horizontal structures affiliated firms were legally separated entities but were interdependent units. These collaborative structures moved opportunistically, in the best sense of the term-reaching out to exploit opportunities to capture niche markets. In the process, they were more likely to be able to reach out to find foreign investors. Paradoxical only on first glance, it was the more cohesive groups that were the more outward looking.

If we had found all firms with cohesive recombinant property forms in pathways 3 and 4, we might conclude that foreign investors who reached in were then permanently captured. Cohesive networks, in that case, would prove entanglements that could not be escaped. Pathway 5 indicates that foreign investment could enter into cohesive topographies and later exit the network. In addition to this late exit another distinctive feature of this pathway is that its sequence shows an abrupt move from cohesive positions to isolation. Recall that large enterprises had spun off firms in the early part of the decade. In 1997 and 1998, some of these firms, and not only those with foreign ownership, dramatically reconfigured their holdings, shutting down or selling off firms to consolidate their positions.

Pathway 6 illustrates that not all formerly state-owned firms used recombinant network strategies to mitigate uncertainties during the period of extrication from state socialism. Unlike the firms in the recombinant pathways, the firms in this pathway, during their long episode of state ownership, are isolated from any network ties. They are privatized in 1995 and simultaneously enter the network as peripheries of large stars. Then, after 1996 - exactly when the period of institutional uncertainty is waning - they gain cohesion, which further increases to strong cohesion. Unlike pathways 3 and 4, however, where cohesion could coexist with

${ }^{14}$ Our findings thus offer further support to prior work by Powell et al. (2005) and Huber and Wörgötter (1998) on performance differences between hierarchically and collaboratively organized business groups. 
foreign participation, in this case, cohesion is not compatible with foreign investment. In itself, being in a cohesive network-even being in a cohesive structure at a critical time-does not ensure foreign investment. In 1997-98, pathways 3, 4, 5, and 6 are all in cohesive clusters or strongly cohesive groups. But pathway 6 is considerably less likely to involve foreign investors.

Creating cohesive networks from the outset has a different meaning than creating them after a long episode of clutching on to the state. For the former, dense networks promoted a process of restructuring, a creative cohesion; for the latter, dense ties fostered a defensive cohesion that, while not entirely excluding foreign investment, was not as open to it.

Start-ups establishing a foothold.-Whereas the first two processes revealed in table 2 involve firms that begin their careers as state-owned enterprises or as the spin-offs of these, the third process involves startups. Many of these new start-ups begin their organizational lives with foreign participation; others quickly acquire foreign investment soon after their establishment. In the transition framework, such new ventures would be unlikely candidates for network participation. But foreign investors were not immune to the uncertainties of postsocialism, and, as we see in pathways 7, 8, and 9, they too use network ties-especially in the earlier period of economic transformation up to the middle of the nineties-as a buffer against uncertainties in policy preferences and changing institutions.

In these pathways, foreign owners are participating in partnerships with state-owned firms as well as enterprises whose owner is another Hungarian corporation. These three pathways represent best the script expected by the previously discussed recent literature on foreign investment in which the foreign actors use network ties as part of strategies for establishing a foothold in the economy at a time when foreign investors were not yet commonplace. As we see in the sequences through the space of local network positions, some of these ties are long lasting, but many are temporary, terminating as legitimacy is established, regulatory uncertainties are mitigated, locally specific knowledge is acquired, and operations are running smoothly. In the case of pathway 8, where foreign companies found new ventures, they tend to cooperate for a relatively short episode as dyads before buying out the domestic partner and thus transforming the joint venture into a wholly owned subsidiary. When foreign investors engage in joint venture strategies with firms that are embedded in denser network ties (in pathway 7), they tend to stay in these positions relatively longer before exiting. In pathway 9 the joint venture survives the entire period, becoming dyads after other ties have been cut in 1995 .

Foreign-led network formation.-Although the overall network tends 
to lose ties and cohesion after 1995, the firms in our fourth group of pathways go against this trend in a process of foreign-led network formation.

Like the firms in pathways 1,3 , and 6 , the firms in pathway 10 have the longest histories, beginning as state-owned enterprises from the period before the regime change. But they also have the longest sequences as isolates. That is, these firms are not only relative latecomers to privatization, but they were also not involved in interorganizational ownership ties with other firms while they were state owned. Firms in pathway 10 enter the network after privatization-in marked contrast to the transition framework that expects that severance of state ownership will be followed by severance of interorganizational ties.

The newest firms in our population, representing the latest developments in network processes, are in pathway 11. Although their organizational lives are much shorter than those of the firms in pathway 10, the two pathways are part of a common process. In each case foreign investors establish joint ventures, but then alongside increasing foreign participation comes rearrangement and rebuilding of network ties (in the sequence of their network positions they move from being in a dyad to being a part of a star-shaped group). The networking represented by these pathways is initiated by foreign subsidiaries. These foreign-held companies are establishing ties with each other and are spinning off their own subsidiaries. That is, foreign investors in this case are not consolidating but are expanding the firms' networks. By 2001, this process of foreignled network formation accounted for more than $30 \%$ of networked-foreign capitalization. In this process, we find FDI not as foreign direct insulation but as foreign-directed embedding.

In the start-up logic, foreign firms create a tie with another company, learn from it, and then typically cut the ties. In the process of foreign-led network formation, however, the sequence goes from a simpler to a more embedded topography. Unlike the earlier, domestic network groups, foreign subsidiaries start building networks from the most elementary form (a dyad) and add ties in a gradual way. The different sequences suggest responses to different environments: whereas the economic context for the evolution of domestic networks in the late eighties and early nineties was radical institutional uncertainty, and the formation of joint ventures in the early nineties represented a strategy to gain legitimacy in a period of political uncertainty, the context of the evolution of foreign-initiated business groups in the midnineties is market competition. In contrast to firms whose existence predated the collapse of the state-socialist economy, foreign firms are relatively more isolated and atomized actors in the economy; nonetheless, they take their positions in chains of inputs and outputs. Foreign owners decide to secure some of their inputs by establishing 
ownership ties to Hungarian firms and start to build business groups similar to those that are integral practices in their home countries (Granovetter 1994; Mizruchi and Galaskiewicz 1994; Podolny 1994; Lincoln, Gerlach, and Ahmadjian 1996).

In doing so, they come into competition with the homegrown networks initiated by postsocialist enterprises. The distinction between foreigngrown versus domestically evolving networks is not only an analytic comparison, but one that actors in the field note as well. Our interviews with corporate consultants indicate that there is often a manifest competition between foreign firms and domestic business groups to buy shares in a valuable supplier, thereby tying it to either a domestic or foreign-driven group.

Isolation.-The fifth process is isolation. Firms in the final pathway are characterized by a relatively late start; none were ever part of the ownership network. Smaller than average, these always-isolated firms are $44 \%$ of the average firm in all the other pathways. Consequently, although about half of the firms in our population are in this pathway, they represent only $30.7 \%$ of the population's capital.

For the population as a whole, foreign investment increased with almost perfect linearity across the time period..$^{15}$ But, as the asterisked figures in table 2 indicate, this linearity in the overall population masks pronounced punctuation at the level of pathways - a further indication that social sequence analysis is tapping distinctive processes of foreign investment. Cohesive recombinants have early, multiple surges of foreign investment, spin-off star structures have none at all, and the processes of start-ups and foreign-led network formation show yet different punctuations. Firms in isolate pathway 12 received a surge of foreign investment in 1997. Always isolated firms do not have a disproportionate share of foreign capital: at $30.4 \%$, their share of total foreign capitalization is almost exactly the same as their share of capital altogether $(30.7 \%)$.

\section{CONCLUSION}

By the term "mixed economy," political economists have typically referred to a mix of private and state ownership. Those categories remain meaningful, but it is worth reflecting on the extent to which they were part of the discourse of the Cold War. In that context, the very term "mixed economy" pointed to a real possibility that a given national economy might, in actual practice, combine features_-of markets and planning, of

\footnotetext{
${ }^{15}$ As a test of linearity we have fitted regression lines to the trends of decreasing state ownership and increasing foreign ownership. The $R^{2}$ of a linear trend line is 0.97 for state ownership and 0.98 for foreign ownership.
} 
private and public property - that were portrayed not only as antagonistic but as mutually exclusive.

In this article, we also use the term "mixed economy." But here we refer not to a mix of state and private property but to an economy that is a mix of foreign and domestic, of networked and isolated firms. Yet whereas we have given the term new content, our intent, at another level, shares much with that of the earlier coinage, here signaling limitations of either/ or choices in the discourse about globalization. Our findings about Hungary's contemporary mixed economy show that developing economies do not necessarily face a forced choice between networks of global reach and those of local embeddedness. High levels of foreign investment can be integrated into processes of interorganizational ownership network formation in a developing economy. Just as interorganizational ownership networks blurred the boundary between state and private ownership in the early nineties, so, from the midnineties, globally linked and domestically integrated business networks blur the boundary between foreign and domestic ownership.

How distinctive is Hungary? Do other postsocialist economies show a similar profile? Is the large firm sector in Russia predominantly networked and domestic? Across the region, from the Baltics to the Balkans, what are the national distributions across our four cells of networked domestic, networked foreign, isolated domestic, and isolated foreign? Our findings invite comparisons among a broader range of cases in various parts of the developing world. A new agenda for the sociology of economic development would call for investigations on the interaction of foreign investment and network evolution comparable to that presented for a 15year period in Hungary (see fig. 1) in countries such as Argentina, Brazil, Vietnam, the Philippines, and South Africa. In short, our methodology to chart the evolving shape of Hungary's mixed economy provides a strong basis for further comparative research across a broad range of developing economies.

The language of "mixed economy," useful for macrostructural overviews, we argued, however, should give way to concepts that are more relational than categorical when attempting to understand the processes of economic transformation. Our approach to property transformation beyond a simple transition from state to private ownership but as restructurings of network properties is an example of this shift from categorical to relational concepts. Similarly, in place of thinking about a simple mix - a whole with identifiably distinctive parts—-we think about mixtures in which the units themselves are combinatory and generative.

Our findings about recombinant property are especially instructive in this light. The motivating question of this study has been less whether national ownership patterns can endure than whether they can be adap- 
tive. Networks provide domestic and foreign actors with resources and opportunities to transform structures. As Powell et al. (2005) demonstrate, interorganizational ties not only respond to institutional environments, they can also change them (see also Padgett 2001). Our study of pathways of property transformation found that the most cohesive type of recombinant property is most likely to involve the participation of foreign investors. This finding indicates that it would be mistaken to characterize networks of recombinant property as mere holdovers of state socialism, as reactionary or backward-looking agents that freeze action or resist change. If they were a legacy of the informal networks of state socialism, they were not, for that reason, condemned to merely replicate themselves. Network structures, like other social patternings, can be repurposed. The cohesive pathways of recombinant property show such generative reformulation (Padgett 2001; Sabel and Zeitlin 1997) with an open potential, first as agents of asset restructuring and later, as this study demonstrates, with potential open to foreign investors. Hungary's transformation from state socialism to an emerging market economy with sizable foreign investment did not occur despite its interorganizational property networks but, in part, because of and through these networks.

To produce a sociological account of historical change, we develop a social sequence analysis. Network analysis has made important strides in moving from static to dynamic modeling. Our goal in this article has been to take the next step-from dynamic network analysis to historical network analysis. We adopt an approach to understanding historical change that is different from categorical studies of transition (e.g., from state ownership to private property) and from dynamic modeling of network systems. In these other approaches, because change is a system-level phenomenon, structure and temporality are both conceptualized at the system level. In our view, by contrast, the transformation of a national economy is not a unitary process obeying a single logic but is formed out of the interweaving of multiple processes with distinctive temporalities (Stark and Bruszt 2001). Instead of collapsing time to before/after dichotomies (as in transition models) or introducing time as a variable (as in dynamic network models), we are alert to the variable structuring of time across different processes. Thus, in place of properties of the global network, we focus on variation in local properties. In place of a single system time, we model the processes of social times. In taking up White's challenge in our epigraph to make social times as much a part of structure as are network spaces, our contribution to a more historical network analysis does not simply include time as a variable but, instead, recognizes time as variable. 
American Journal of Sociology

\section{APPENDIX A}

Methodology: Identifying Significant Foreign Ownership

To assess the distribution of firms according to the concentration/dispersion of ownership, we used Ward hierarchical cluster analysis to find typical patterns of ownership based on the percentage shares held by a firm's first largest owner, second largest, third, fourth, and fifth for every year in which it existed as a company. Because dispersed ownership is exceedingly rare in our population of the largest enterprises, a two-cluster model is appropriate for representing ownership structure. An ownership structure with a dominant owner accounts for $45 \%$ of all firm years. In this first cluster, the dominant owner holds, on average, $98 \%$ of the shares, while the second owner holds less than $2 \%$. Second owners in this cluster are not classified as significant owners. The second cluster represents a coalitional structure in which the first owner holds, on average, $51 \%$ of the shares, while the second holds $25 \%$. If either the first or the second owner of firms in this coalitional cluster is a foreign owner, the firm is classified as having significant foreign ownership.

\section{APPENDIX B}

\section{Methodology: Simulation Test of the Random Change Hypothesis}

To test the hypothesis that the network change we record is merely a result of a random walk process, we run network simulations. For each pair of years we observed the number of broken ties and new ties. We can simulate the change of the network from one year to the next by randomly breaking the same number of ties observed to be broken in the given year and randomly assigning the same number of new ties observed to be created. If the frequency of the various local network positions is not significantly different in our observed data and in the simulations, we cannot reject that network change from the first year to the next was a result of a random process.

For each pair of consecutive years from 1987 to 2001 we ran 1,000 random simulations of network change to compare simulated and observed frequencies of dyad, star-periphery, star-center, and cohesive group local network positions. Throughout the period there are more cohesive positions and fewer star centers than we would expect by random change. In the early years (1989-90) and at the very end of our period there are more dyads and star peripheries than would be expected if the changes were random. As an illustration, for the cohesive positions we display for each year the box plots of the frequencies in the simulation together with the observed frequencies on figure B1. For every year, except 1989 and 


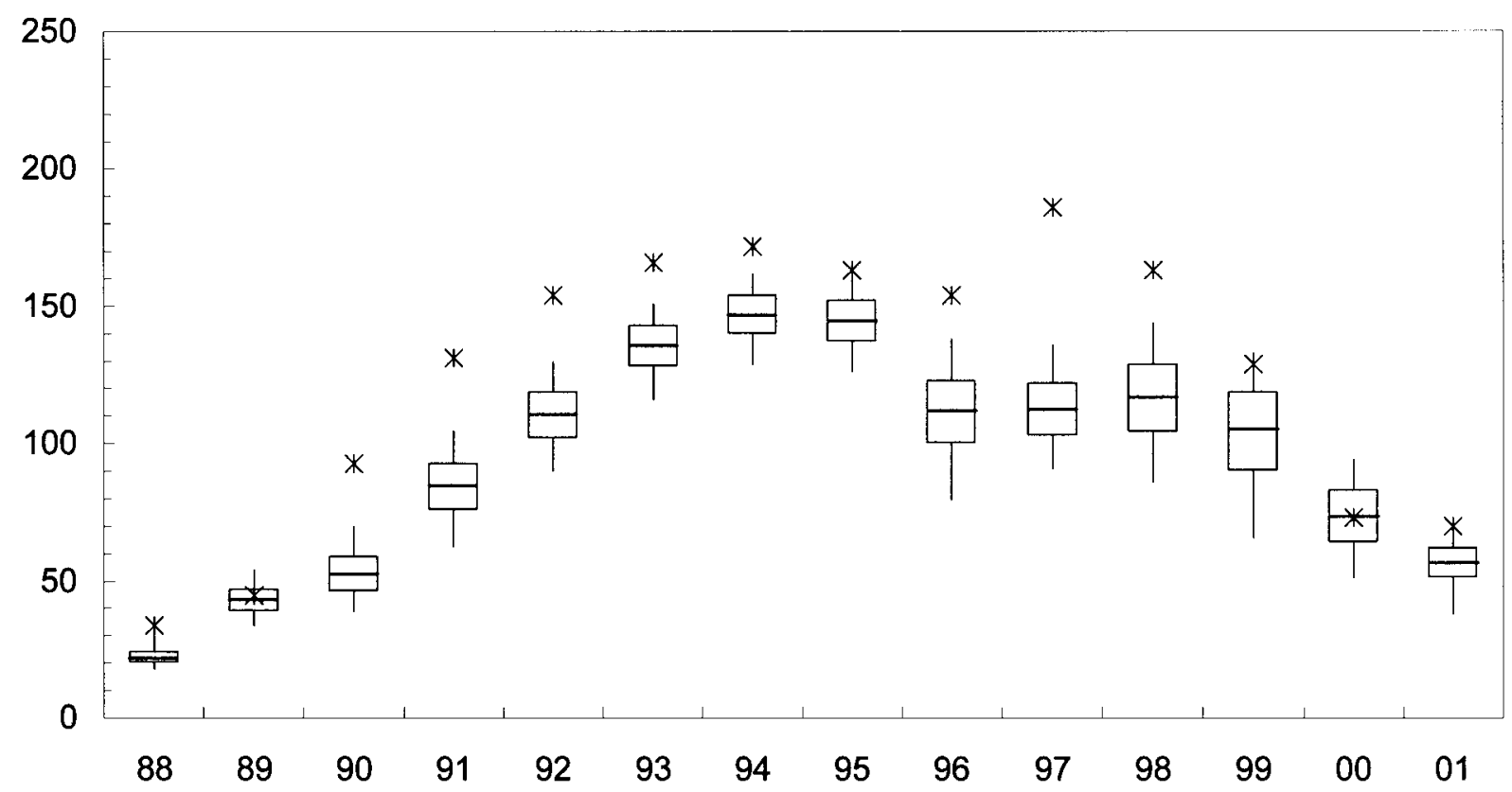

FIG. B1.-Cohesive neighborhoods in observed and simulated data. Asterisks indicate frequencies in observed data, box-and-whiskers plot indicates simulation results. Box indicates interquartile range, whiskers indicate range between the fifth and ninety-fifth percentile. 
American Journal of Sociology

2000, network change from one year to the next produces more cohesion than we would expect in a random walk process.

\section{APPENDIX C}

\section{Methodology: Parameters Used in Optimal Matching}

Sequence analysis has recently been criticized by Wu (2000) for using an algorithm that is insensitive to the direction of transitions. As Wu rightly points out, a social science of optimal matching analysis must be able to distinguish the sequence of going from employment to unemployment from the sequence going from unemployment to employment. Indeed, the prevalent optimal matching algorithm, adopted from natural sciences, does not have a concept of temporality built into it. In this appendix we briefly outline how we modified the optimal matching algorithm to maximize the method's sensitivity to temporal ordering.

Two types of parameters can be adjusted to adapt optimal matching analysis for our purposes: the cost of inserting or deleting elements (the indel cost), and the cost of replacing elements (substitution costs; Abbott and Hrycak 1990). Our aim is to adjust these two parameters so that their combination maximizes temporal sensitivity.

We start with the extant version of the algorithm (the so-called longest common subsequence method; Sankoff and Kruskal 1999), as the baseline version we seek to improve. Sociologists have proposed adjustments to the cost parameters of the optimal matching algorithm (Abbott 1995; Blair-Loy 1999; Stovel et al. 1996), but they have not systematically tested whether and how these adjustments improve temporal sensitivity. We test these previously proposed adjustments and specify our final cost schedule to maximize this sensitivity.

We measure temporal similarity between two sequences by a matching coefficient that counts the matches when two sequences, $a$ and $b$, were in the same state in the same year, divided by the length of the shorter sequence. This metric is one if the two sequences are the same or the shorter sequence is completely contained within the longer. The metric is zero if there is no match at all between the two sequences. We use a second measure to capture reverse temporality. This second measure is a matching coefficient between sequence $a$ and the reverse of sequence $b$. The coefficient is calculated the same way. In this case, a coefficient of one means that sequence $b$ is the exact reverse of sequence $a$. Our goal is to find cost parameters for optimal matching that reward similarity in temporal ordering and punish similarity in reverse temporal ordering.

We ran optimal matching analyses with various cost parameters, recording the resulting dyadic distance matrices for each. We created a data 
set with dyads as cases (all together there were 359,128 dyads between the 848 sequences), with optimal matching distances as one set of variables and the matching and reverse-matching coefficients as another. We then used linear regression models with optimal matching distance as the dependent variable and the matching and reverse-matching coefficients as independent variables. Table $\mathrm{C} 1$ reports the regression coefficients for four models, with four different dependent variables: optimal matching distances with the longest common subsequence approach (model 1), with the same constant substitution costs and twice as expensive indel cost (model 2), with a structured substitution cost matrix based on transition frequencies (model 3), and our final model with a slightly higher indel cost (model 4).

Our linear regression analysis indicates that the baseline version of the optimal matching algorithm (the longest common subsequence approach) is indeed insensitive toward temporal ordering. The coefficients of both matching and reverse matching are negative, indicating that the algorithm records a smaller distance between sequences that are similar regardless of directionality. As the second model indicates, making the cost of insertions and deletions higher effectively increases the sensitivity of the method for temporal ordering. In model 2 the coefficient for matches is negative (sequences that go through the same states with the same timing are closer), while the coefficient of reverse matching becomes positive, indicating that optimal matching with increased indel cost now penalizes reverse temporal similarity between sequences. Restating this finding in terms of the example raised by $\mathrm{Wu}(2000)$, we can say that in model 2 the sequence of employment to unemployment is now seen as different from the sequence of unemployment to employment. The third model employs a structured substitution cost matrix derived from transition probabilities (see details below). This model is even less likely to group sequences with reverse temporality as similar (it has a higher positive coefficient of reverse matching than in the previous model).

Our final model (model 4) fine-tunes both the substitution cost matrix and the indel cost. We defined substitution costs in the following way: the cost of substituting two nonisolate positions is proportional to the relative frequency of the transitions from one position to the other in the whole sequence data set. The substitution costs are defined by first calculating transition probabilities:

$$
p(x, y)=\frac{\sum_{t=1}^{T-1} N_{t, t+1}(x, y)}{\sum_{t=1}^{T-1} N_{t}(x)},
$$


American Journal of Sociology

TABLE C1

Linear Regression Models of Optimal Matching Distances and Matches and Reverse Matches between Sequences

\begin{tabular}{|c|c|c|c|c|}
\hline & $\begin{array}{c}\text { Model 1: } \\
\text { Longest } \\
\text { Common } \\
\text { Subsequences }\end{array}$ & $\begin{array}{c}\text { Model 2: } \\
\text { Expensive Indel }\end{array}$ & $\begin{array}{c}\text { Model 3: } \\
\text { Structured } \\
\text { Substitutions }\end{array}$ & $\begin{array}{l}\text { Model 4: } \\
\text { Final Model }\end{array}$ \\
\hline \multicolumn{5}{|l|}{ Optimal matching parameters: } \\
\hline Indel cost $\ldots \ldots \ldots \ldots \ldots$ & 1.00 & 2.00 & 2.00 & 2.01 \\
\hline Substitution costs $\ldots \ldots \ldots$. & Constant $=2.00$ & Constant $=2.00$ & Structured & Structured \\
\hline \multicolumn{5}{|l|}{ Linear regression: ${ }^{a}$} \\
\hline Matches ....... & -18.346 & -26.903 & -20.882 & -20.912 \\
\hline Reverse matches $\ldots \ldots \ldots \ldots$ & -7.046 & 4.047 & 5.499 & 5.658 \\
\hline Constant $\ldots \ldots \ldots \ldots \ldots \ldots$ & 22.790 & 25.355 & 19.726 & 19.753 \\
\hline 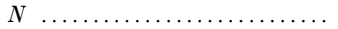 & 359,128 & 359,128 & 359,128 & 359,128 \\
\hline$R^{2} \ldots \ldots \ldots \ldots \ldots \ldots \ldots$ & .575 & .714 & .439 & .437 \\
\hline
\end{tabular}

${ }^{a}$ All coefficients are significant at the $P<0.0001$ level.

where $x$ and $y$ are network positions. Then from transition probabilities the costs are calculated by the following formula:

$$
\omega\left(a_{i}, b_{j}\right)=2-p\left(a_{i}, b_{j}\right)-p\left(b_{j}, a_{i}\right) \text { if } a_{i} \neq b_{j},
$$

where $a$ and $b$ are two sequences. Substitution costs range between zero and two. A cost of zero only occurs if one network position always follows the other and vice versa. Although this is not likely, substitution costs will be low for network positions that very frequently follow one another. The assumption behind this is that if it is relatively easy to step from one network position to another, these network positions should make a relatively small difference between sequences. That is, if the only difference between two sequences is that one of them is in state $a$ at time $t$, while the other is in state $b$ at the same time $t$, then the distance between these two sequences is a function of the similarity between states $a$ and $b$, which is in turn read from the transition frequencies (displayed in table C2).

There are two states that are not substituted with a cost proportional to transition probabilities: the isolate state and the nonexistence state. We

TABLE C2

Frequency of Transitions between Local Network Positions

\begin{tabular}{lrrrrrrr}
\hline \hline & \multicolumn{1}{c}{ I } & \multicolumn{1}{c}{ D } & \multicolumn{1}{c}{ P } & \multicolumn{1}{c}{ L } & \multicolumn{1}{c}{ S } & C & G \\
\hline I $\ldots$ & 2,687 & 167 & 192 & 35 & 19 & 43 & 42 \\
D . $\ldots$ & 138 & 849 & 79 & 2 & 44 & 8 & 4 \\
P $\ldots$ & 167 & 71 & 1,342 & 22 & 37 & 91 & 31 \\
L $\ldots$ & 18 & 0 & 26 & 181 & 0 & 33 & 1 \\
S $\ldots$ & 12 & 28 & 35 & 0 & 353 & 37 & 7 \\
C $\ldots$ & 47 & 16 & 100 & 15 & 42 & 497 & 109 \\
G $\ldots$ & 44 & 4 & 39 & 8 & 8 & 129 & 462 \\
\hline
\end{tabular}


TABLE C3

Substitution Costs

\begin{tabular}{lcccccccc}
\hline \hline & & & & & & & & \multicolumn{2}{c}{$\begin{array}{c}\text { Dummy } \\
\text { State }\end{array}$} \\
\hline $\mathrm{I} \ldots \ldots \ldots \ldots \ldots \ldots \ldots$ & & 2.00 & 2.00 & 2.00 & 2.00 & 2.00 & 2.00 & 1.00 \\
$\mathrm{D} \ldots \ldots \ldots \ldots \ldots \ldots$ & 2.00 & & 1.97 & 1.99 & 1.90 & 1.89 & 2.00 & 1.00 \\
$\mathrm{P} \ldots \ldots \ldots \ldots \ldots \ldots$ & 2.00 & 1.97 & & 1.69 & 1.87 & 1.83 & 1.86 & 1.00 \\
$\mathrm{~L} \ldots \ldots \ldots \ldots \ldots \ldots$ & 2.00 & 1.99 & 1.69 & & 1.97 & 1.93 & 1.98 & 1.00 \\
$\mathrm{~S} \ldots \ldots \ldots \ldots \ldots \ldots$ & 2.00 & 1.90 & 1.87 & 1.97 & & 1.91 & 2.00 & 1.00 \\
$\mathrm{C} \quad \ldots \ldots \ldots \ldots \ldots \ldots$ & 2.00 & 1.89 & 1.83 & 1.93 & 1.91 & & 1.89 & 1.00 \\
$\mathrm{G} \ldots \ldots \ldots \ldots \ldots$ & 2.00 & 2.00 & 1.86 & 1.98 & 2.00 & 1.89 & & 1.00 \\
Dummy state $\ldots$ & 1.00 & 1.00 & 1.00 & 1.00 & 1.00 & 1.00 & 1.00 & \\
\hline
\end{tabular}

assign a high (maximal, i.e., two) cost to substituting an isolate state. Because we are interested in ways of participating in the network, the moment of entering or exiting the network is especially important. We have made the substitution of an isolate state expensive (a cost of two), because the distinction between being part of the network and being out of it is important for us. If the only difference between two sequences is that one is isolated in year $t$, and the other is part of the network, this should make a bigger difference between them than any form of network participation. We assign a low cost (1) for the substitution of the nonexistence state. In doing so we make the algorithm less sensitive to differences in the length of the life of a firm and more sensitive to its network career. See the final substitution cost matrix in table C3.

To specify the optimal indel cost we run regression models with our substitution cost matrix, varying the indel cost between 1 and 2.5. We found that the maximal coefficient for reverse matching (that is, with the most aversion to grouping sequences with reverse temporality together) occurs when the indel cost equals 2.01. As displayed in table 3 the coefficient for reverse matching for an optimal-matching model with indel cost 2.01 is 5.658. The coefficients for 2.00 and 2.02 are 5.499 and 5.506. The 2.01 indel cost equals the maximal substitution cost plus the difference between the maximal and the second-largest substitution cost, suggested by Abbot and Hrycak (1990).

\section{APPENDIX D}

\section{Methodology: Constructing Ideal-Typical Sequences}

We construct ideal-typical sequences to represent each pathway of clustered sequences. Our task is to identify the characteristic states of a pathway's ideal-typical sequence, as well as the typical timing of transitions 


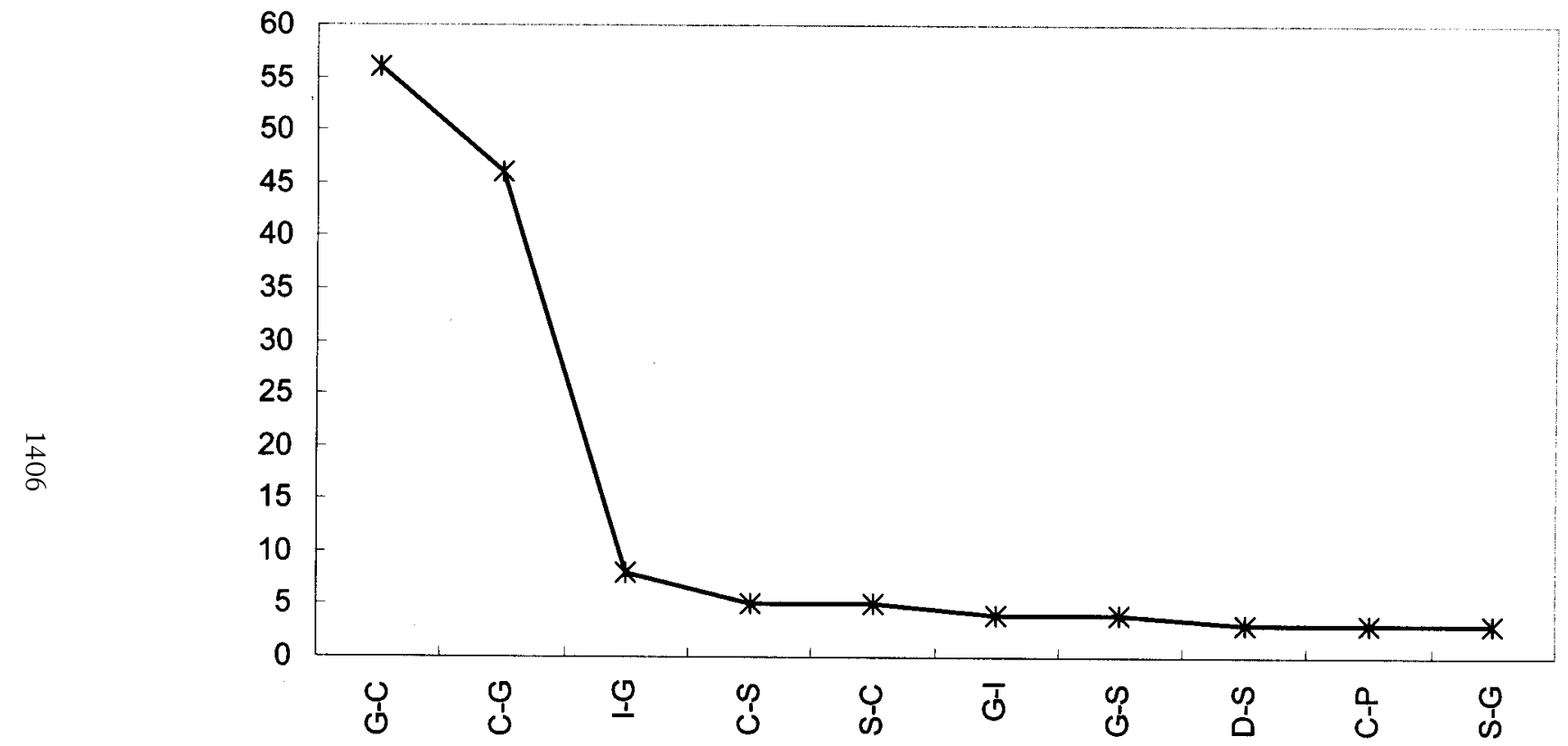

FIG. D1.-Scree plot of transition frequencies in pathway 4. The vertical axis shows the frequencies of transitions, the horizontal axis lists transitions in a descending order of frequency. For example, "G-C" indicates the transition from local position G (strongly cohesive group member) to C (cohesive cluster member). 


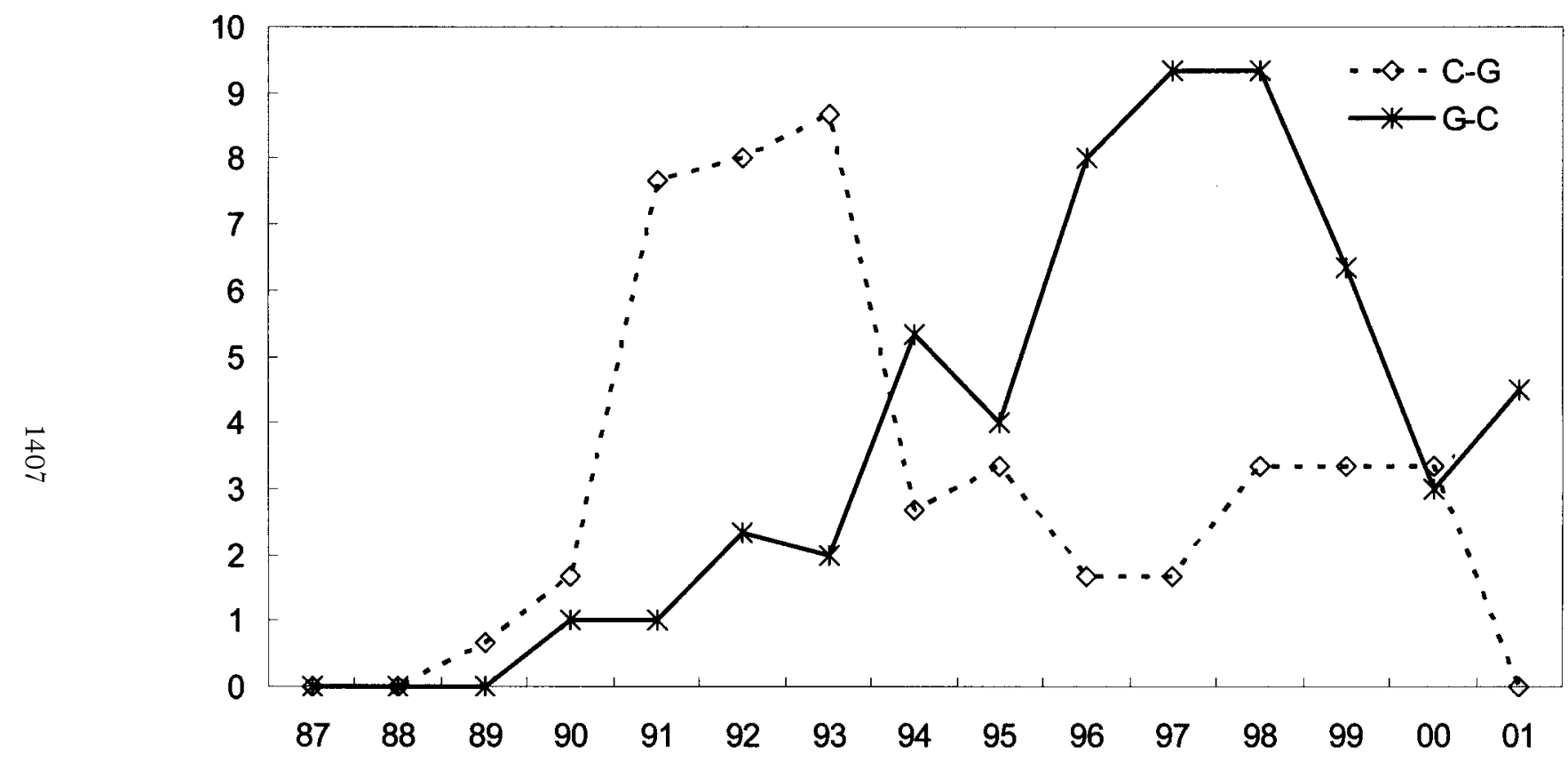

FIG. D2.-Frequencies of characteristic transitions by time in pathway 4, smoothed by a three-year moving average 
American Journal of Sociology

between these states. To do so, we analyze the distribution of transitions by constructing a scree plot that represents the transitions in a decreasing order of their frequencies. See figure D1 for an example of such a scree plot, constructed for the fourth pathway.

From this scree plot we identified highly frequent transitions as characteristic features of the pathway. For example, for pathway 4 we identified the transitions "G-C" (strongly cohesive group member to cohesive cluster member), and " $\mathrm{C}-\mathrm{G}$ " (cohesive cluster member to strongly cohesive group member). To identify the timing in which these characteristic transitions occurred, we produced plots of the transition frequencies by year, smoothing with a three-year moving average. Figure D2 presents this chart for the fourth pathway. In the case of this pathway, we thus chose 1992 as the transition from cohesive to strongly cohesive (C to G), and 1997 as the year for the transition back from strongly cohesive to cohesive (G to $\mathrm{C})$.

\section{REFERENCES}

$\rightarrow$ Abbott, Andrew. 1995. "Sequence Analysis: New Methods for Old Ideas." Annual Review of Sociology 21:93-113.

$\rightarrow$ 1997. "Of Time and Space: The Contemporary Relevance of the Chicago School." Social Forces 75:1149-82.

$\rightarrow$ Abbott, Andrew, and Alexandra Hrycak. 1990. "Measuring Resemblance in Sequence Data: An Optimal Matching Analysis of Musicians' Careers." American Journal of Sociology 96:144-85.

$\rightarrow$ Arthur, Brian W. 1989. "Competing Technologies, Increasing Returns, and Lock-In by Historical Events.” Economic Journal 99 (394): 116-31.

$\rightarrow$ Bair, Jennifer, and Gary Gereffi. 2003. "Upgrading, Uneven Development, and Jobs in the North American Apparel Industry." Global Networks 3:143-69.

$\rightarrow$ Blair-Loy, Mary. 1999. "Career Patterns of Executive Women in Finance: An Optimal Matching Analysis." American Journal of Sociology 104:1346-97.

$\rightarrow$ Böröcz, József. 2001. "Change Rules." American Journal of Sociology 106:1152-68.

$\rightarrow$ Brudner, Lilyan A., and Douglas R. White. 1997. "Class, Property, and Structural Endogamy: Visualizing Networked Histories." Theory and Society 26:161-208.

$\rightarrow$ Buckley, Peter J., and Mark C. Casson. 1998. "Models of the Multinational Enterprise." Journal of International Business Studies 29:21-44.

$\rightarrow$ Burawoy, Michael. 1996. "The State and Economic Involution: Russia through a Chinese Lens." World Development 24:1105-17.

$\rightarrow$ Burawoy, Michael, and Pavel Krotov. 1992. "The Soviet Transition from Socialism to Capitalism: Worker Control and Economic Bargaining in the Wood Industry." American Sociological Review 57:16-38.

Comisso, Ellen. 1998. "'Implicit' Development Strategies in Central and East Europe and Cross-National Production Networks." Working Paper. University of California, Berkeley, Berkeley Roundtable on International Economy.

$\rightarrow$ Davis, James A. 1970. "Clustering and Hierarchy in Interpersonal Relations: Testing Two Graph Theoretical Models on 742 Sociomatrices." American Sociological Review 35 (5): 843-51.

Dicken, P., M. Forsgren, and A. Malmberg. 1994. "The Local Embeddedness of Transnational Corporations." Pp. 23-45 in Holding Down the Global: Possibilities 
for Local Economic Prosperity, edited by Ash Amin and Nigel Thrift. Oxford: Oxford University Press.

Evans, Peter B. 1995. Embedded Autonomy: States and Industrial Transformation. Princeton, N.J.: Princeton University Press.

Ferligoj, Anuska, Janez Prasnikar, and Marko Pahor. 2001. "Ownership and Board Interlock Networks of the Largest Slovenian Firms." Manuscript. Ljubljana University.

Figyelő. 2002. "Kétszázak klubja 2001." In Figyelö Top 200.

$\rightarrow$ Gereffi, Gary, and Stephanie Fonda. 1992. "Regional Paths to Development." Annual Review of Sociology 18:419-48.

$\rightarrow$ Ghoshal, Sumantra, and Christopher A. Bartlett. 1990. "The Multinational Corporation as an Interorganizational Network." Academy of Management Review 15:603-25.

$\rightarrow$ Giuffre, Katherine. 1999. "Sandpiles of Opportunity: Success in the Art World." Social Forces 77:815-32.

Grabher, Gernot. 1994. "The Dis-embedded Economy: The Transformation of East German Industrial Complexes into Western Enclosures." Pp. 177-96 in Globalization, Institutions, and Regional Development in Europe, edited by Ash Amin and Nigel Thrift. Oxford: Oxford University Press.

Granovetter, Mark. 1994. "Business Groups." Pp. 453-75 in The Handbook of Economic Sociology, edited by Neil J. Smelser and Richard Swedberg. Princeton, N.J.: Princeton University Press.

$\rightarrow$ Han, Shin-Kap, and Phyllis Moen. 1999. "Clocking Out: Temporal Patterning of Retirement." American Journal of Sociology 105:191-236.

$\rightarrow$ Hanley, Eric, Lawrence King, and István János Tóth. 2002. "The State, International Agencies, and Property Transformation in Postcommunist Hungary." American Journal of Sociology 108:129-67.

$\rightarrow$ Hardy, Jane. 1998. "Cathedrals in the Desert? Transnationals, Corporate Strategy and Locality in Wroclaw." Regional Studies 32:639-52.

Hedlund, Gunnar. 1993. "Assumptions of Hierarchy and Heterarchy, with Applications to the Management of the Multinational Corporation." Pp. 211-36 in Organization Theory and the Multinational Corporation, edited by Sumantra Ghoshal and Eleanor D. Westney. New York: Saint Martin's.

Huber, P., and A. Wörgötter. 1998. "Political Survival or Entrepreneurial Development? Observations on Russian Business Networks." Pp. 51-65 in The Tunnel at the End of the Light: Privatization, Business Networks, and Economic Transformation in Russia, edited by Stephen S. Cohen, Andrew Schwartz, and John Zysman. International and Area Studies Research Series, no. 100. Berkeley and Los Angeles: University of California.

$\rightarrow$ Inkpen, Andrew C., and Paul W. Beamish. 1997. "Knowledge, Bargaining Power, and the Instability of International Joint Ventures." Academy of Management Review 22:177-202.

Johnson, Juliet. 1997. "Russia's Emerging Financial-Industrial Groups.” Post-Soviet Affairs 13:333-65.

$\rightarrow$ Keister, Lisa A. 1998. "Engineering Growth: Business Group Structure and Firm Performance in China's Transition Economy." American Journal of Sociology 104 (2): 404-40.

$\rightarrow$ 2001. "Exchange Structures in Transition: Lending and Trade Relations in Chinese Business Groups.” American Sociological Review 66:336-60.

$\rightarrow$ Kogut, Bruce. 1988. "Joint Ventures: Theoretical and Empirical Perspectives." Strategic Management Journal 9:319-32.

$\rightarrow \longrightarrow$. 1991. "Joint Ventures and the Option to Expand and Acquire." Management Science 37:19-33.

Kogut, Bruce, W. Shan, and Gordon Walker. 1992. "The Make-or-Cooperate Decision in the Context of an Industry Network." Pp. 348-65 in Networks and Organizations: 
American Journal of Sociology

Structure, Form and Action, edited by Nitrin Nohria and R. G. Eccles. Boston: Harvard Business School Press.

$\rightarrow$ Kogut, Bruce, and Gordon Walker. 2001. "The Small World of Germany and the Durability of National Networks." American Sociological Review 66:317-35.

$\rightarrow$ Levine, Joel H. 2000. "But What Have You Done for Us Lately?" Sociological Methods and Research 29:34-40.

$\rightarrow$ Lincoln, James R., Michael L. Gerlach, and Christina L. Ahmadjian. 1996. "Keiretsu Networks and Corporate Performance in Japan." American Sociological Review 61: $67-88$.

$\rightarrow$ Mahoney, James. 2000. "Path Dependence in Historical Sociology." Theory and Society 29 (4): 83-94.

McDermott, Gerald A. 1997. "Renegotiating the Ties That Bind: The Limits of Privatization in the Czech Republic." Pp. 70-106 in Restructuring Networks in Postsocialism: Legacies, Linkages, and Localities, edited by Gernot Grabher and David Stark. Oxford: Oxford University Press.

Mizruchi, Mark S., and Joseph Galaskiewicz. 1994. "Networks of Interorganizational Relations." Pp. 230-53 in Advances in Social Network Analysis, edited by Stanley Wasserman and Joseph Galaskiewicz. Thousand Oaks, Calif.: Sage.

Morgan, Glenn, Peer Hull Kristensen, and Richard Whitley. 2001. The Multinational Firm: Organizing across Institutional and National Divides. New York: Oxford University Press.

Padgett, John F. 2001. "Organizational Genesis, Identity, and Control: The Transformation of Banking in Renaissance Florence." Pp 211-57 in Networks and Markets, edited by James Rauch and Alessandra Casella. New York: Russell Sage.

$\rightarrow$ Pavlinek, Petr, and Adrian Smith. 1998. "Internationalization and Embeddedness in East-Central European Transition: The Contrasting Geographies of Inward Investment in the Czech and Slovak Republics." Regional Studies 32:619-38.

$\rightarrow$ Podolny, Joel M. 1994. "Market Uncertainty and the Social Character of Economic Exchange." Administrative Science Quarterly 39:458-83.

$\rightarrow$ Powell, Walter W., Kenneth Koput, Douglas R. White, and Jason Owen-Smith. 2005. "Network Dynamics and Field Evolution: The Growth of Interorganizational Collaboration in the Life Sciences." American Journal of Sociology 110 (4): 1132-1205.

Rohver, Götz, and Ulrich Pötter. 2002. TDA: A Program for Transition Data Analysis. Bochum: Ruhr-Universität.

Róna-Tas, Ákos. 1998. "Path Dependence and Capital Theory: Sociology of the PostCommunist Economic Transformation." East European Politics and Societies 12: $107-31$.

Sabel, Charles F., and Jonathan Zeitlin. 1997. "Stories, Strategies, Structures: Rethinking Historical Alternatives to Mass Production.” Pp. 1-33 in World of Possibilities: Flexibility and Mass Production in Western Industrialization, edited by Charles F. Sabel and Jonathan Zeitlin. Cambridge: Cambridge University Press.

Sankoff, David, and Joseph P. Kruskal. 1999. Time Warps, String Edits And Macromolecules: The Theory and Practice Of Sequence Comparison. Stanford: CSLI Publications.

$\rightarrow$ Snijders, Tom A. B. 2001. "The Statistical Evaluation of Social Network Dynamics." Sociological Methodology 31 (1): 361-95.

$\rightarrow$ Spicer, Andrew, Gerald A. McDermott, and Bruce Kogut. 2000. "Entrepreneurship and Privatization in Central Europe: The Tenuous Balance between Destruction and Creation." Academy of Management Review 25:630-49.

$\rightarrow$ Stark, David. 1996. "Recombinant Property in East European Capitalism." American Journal of Sociology 101:993-1027.

—. 2001. "Ambiguous Assets for Uncertain Environments: Heterarchy in Postsocialist Firms.” Pp. 69-104 in The Twenty-First-Century Firm: Changing 
Economic Organization in International Perspective, edited by Paul DiMaggio. Princeton, N.J.: Princeton University Press.

Stark, David, and Laszlo Bruszt. 1998. Postsocialist Pathways: Transforming Politics and Property in East Central Europe. New York: Cambridge University Press.

$\rightarrow$. 2001. "One Way or Multiple Paths? For a Comparative Sociology of East European Capitalism.” American Journal of Sociology 106 (4): 1129-37.

$\rightarrow$ Stovel, Katherine. 2001. "Local Sequential Patterns: The Structure of Lynching in the Deep South, 1882-1930." Social Forces 79 (3): 843-80

$\rightarrow$ Stovel, Katherine, Michael Savage, and Peter Bearman. 1996. "Ascription into Achievement: Models of Career Systems at Lloyds Bank, 1890-1970." American Journal of Sociology 102:358-99.

$\rightarrow$ Stuart, Toby E. 1998. "Network Positions and Propensities to Collaborate: An Investigation of Strategic Alliance Formation in a High-Technology Industry." Administrative Science Quarterly 43:668-98.

$\rightarrow$ Uhlir, David. 1998. "Internationalization, and Institutional and Regional Change: Restructuring Post-communist Networks in the Region of Lanskroun, Czech Republic." Regional Studies 32 (7): 673-85.

$\rightarrow$ Uzzi, Brian. 1997. "Social Structure and Competition in Interfirm Networks: The Paradox of Embeddedness." Administrative Science Quarterly 42:35-67.

Vedres, Balázs. 2000. "The Constellations of Economic Power: The Position of Political Actors, Banks and Large Corporations in the Network of Directorate Interlocks in Hungary, 1997." Connections 23:44-59.

Voszka, Éva. 1997. A dinoszauruszok esélyei (The chances of dinosaurs). Budapest: Pénzügykutató Rt.

$\rightarrow$ Ward, Joe H., Jr. 1963. "Hierarchical Grouping to Optimize an Objective Function." Journal of the American Statistical Association 58:236-44.

Wasserman, Stanley, and Katherine Faust. 1994. Social Network Analysis: Methods and Applications. New York: Cambridge University Press.

$\rightarrow$ Watts, Duncan. 1999. "Networks, Dynamics, and the Small-World Phenomenon." American Journal of Sociology 105:493-527.

$\rightarrow$ White, Douglas. 2004. "Network Analysis, Social Dynamics and Feedback in Social Systems." Cybernetics and Systems 35:172-92.

White, Harrison C. 1992. Identity and Control. Princeton, N.J.: Princeton University Press.

Wishart, David. 2003. ClustanGraphics 5: Cluster Analysis Program. Clustan Ltd

$\rightarrow \mathrm{Wu}$, Lawrence L. 2000. "Some Comments on "Sequence Analysis and Optimal Matching Methods in Sociology: Review and Prospect."' Sociological Methods and Research 29:41-64.

$\rightarrow$ Yiu, Daphne, and Shige Makino. 2002. "The Choice between Joint Venture and Wholly Owned Subsidiary: An Institutional Perspective." Organization Science 13:667-83.

$\rightarrow$ Zaheer, Srilata. 1995. "Overcoming the Liability of Foreignness." Academy of Management Journal 38:341-63.

$\rightarrow$ Zon, Hans Van. 1998. "The Mismanaged Integration of Zaporizhzhya with the World Economy: Implications for Regional Development in Peripheral Regions." Regional Studies 32:607-18.

Zysman, John, and Andrew Schwartz. 1998. "Reunifying Europe in an Emerging World Economy: Economic Heterogeneity, New Industrial Options, and Political Choices." Working paper, Berkeley Roundtable on International Economy. University of California, Berkeley. 